UNIVERSITY OF CALIFORNIA

COLLEGE OF AGRICULTURE

AGRICULTURAL EXPERIMENT STATION

BERKELEY, CALIFORNIA

CIRCULAR 342

July, 1937

Revised September, 1941

\title{
ANTS AND THEIR CONTROL IN CALIFORNIA ${ }^{1}$
}

J. E. ECKERT ${ }^{2}$ AND ARNOLD MALLIS ${ }^{3}$

ANTS HAVE OCCUPIED THE ATTENTION of man from early times because of their almost universal distribution, their interesting habits of life, and their general economic importance in the field and home. They are found everywhere on land, from the highest mountains to areas below sea level, from deserts to dense forests. In total numbers they far exceed any other group of terrestrial animals. Like the social bees, termites, and wasps, individual ants cannot survive alone but must live in association so they can profit by the extraordinary adaptability of the entire population to changes in the external environment. Unlike the other social insects, however, the ants have so specialized their mode of living as to become responsive to changing conditions and less dependent upon a definite habitation. They do not require complex materials with which to build their nests nor specially fabricated compartments in which to rear their young. Their nests may be found in the open ground, under stones or wood, in decaying trees, or in any structure that affords the desired protection. They can transport their eggs, larvae, or pupae (figs. 1, 2, 3, and 4) from one place to a more favorable location at a moment's notice and thus are not bound to any particular situation.

Ants have another distinct advantage in that the span of life of the individual is much greater than for most social insects, extending over years instead of only a few weeks or months. They are also comparatively free of enemies, their greatest menace being other species of their own family.

${ }^{1}$ This publication supersedes Circular 38, The Argentine Ant in California, and Bulletin 207, The Control of the Argentine Ant, both by C. W. Woodworth.

${ }^{2}$ Associate Professor of Entomology and Associate Apiculturist in the Experiment Station.

${ }^{3}$ Graduate Student in Entomology, 1934-1939. 


\section{LIFE HISTORY AND HABITS}

All ants belong to a single large superfamily-the Formicoidea-composed of some 8,000 or more described species, subspecies, and varieties.

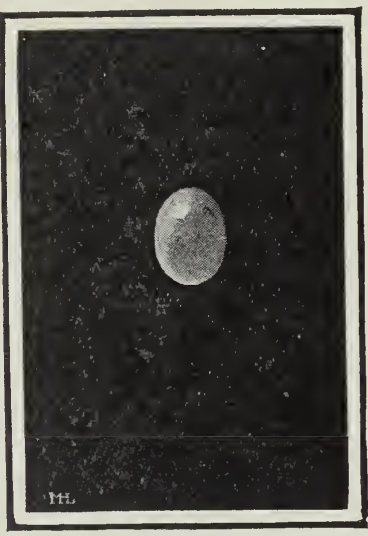

Fig. 1.-The egg of the Argentine ant, greatly enlarged. (From Bul. 207.)

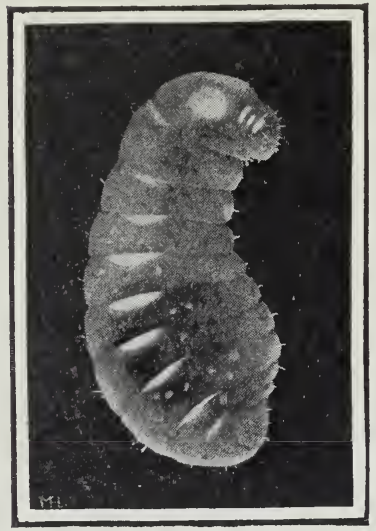

Fig. 3.-A full-grown larva of the Argentine ant, greatly enlarged. (From Bul. 207.)

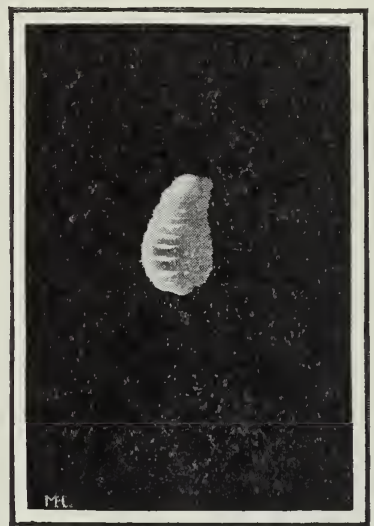

Fig. 2.-A very young larva of the Argentine ant, greatly enlarged. (From Bul. 207.)

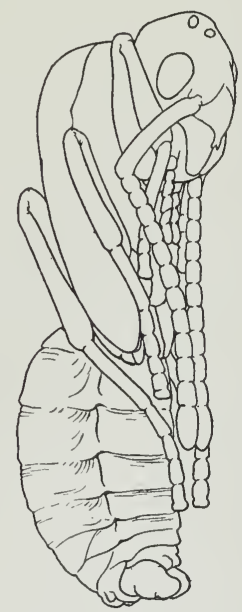

Fig. 4.-The pupa of a queen of the odorous house ant (Tapinoma sessile), greatly enlarged. (From Bul. 207.)

In California approximately 175 different species have been identified, and many others are undoubtedly present. Fortunately, however, only 
a very small percentage of this number have noxious habits of any great economic importance. On the other hand, many species are beneficial primarily through aiding in the destruction of organic substances and of living insects. Most of the smaller forms of animal life and particularly insect life that die are soon cut up and devoured by ants. The extent of this one service alone to mankind is often overlooked or underestimated.

The noxious ants cause injury in many ways. Some invade dwellings and make forays on sweet or fatty substances. The mere presence of ants searching for food in the kitchen, pantry, storeroom, or warehouse causes most persons to attempt drastic means of exterminating them. The Argentine ant is, without doubt, the most important household pest in California (fig. 7). Also important in this regard are the odorous house ant, the California velvety tree ant, the pyramid ant, the California fire ant, the western thief ant, Pharaoh's ant, the tiny black ant, the pavement ant, and the carpenter ants of the genus Camponotus. At times certain species of the field ants, of the genus Formica, as well as other forms, may be temporary invaders of the home.

Besides being household pests, ants may damage lawns, gardens, seedbeds, fields, or orchards by their nesting habits and by destroying plants, fruits, seeds, and nuts. Certain field ants feed on the saccharine excretions (honeydew) of plant-sucking insects such as mealybugs (Coccidae), tree hoppers (Membracidae), and aphids (plant lice), which they have formed the habit of pasturing and guarding. Sometimes such ants must be destroyed in order to control other destructive insect forms. In California, the Argentine ant is the most important offender in the field and orchard in caring for honeydew-excreting insects. The agricultural or harvester ants, Pogonomyrmex spp. and Veromessor spp., cause considerable damage by clearing areas of plant growth near their nests. Such individual clearings may cover areas several feet in diameter and thus considerably reduce the crops. Some ants invade poultry houses and attack young chicks. These same ants may also be beneficial, however, by invading the nests of mice and rats and killing their young. Carpenter ants not infrequently cause considerable damage to the rafters and walls of houses, especially those constructed of logs in mountain locations. They also injure telephone poles to such an extent by their excavations as to make them unserviceable.

General Shape and Size of Ants.-Ants are so common that their general form is well known. The head, thorax, and abdomen are sharply constricted into separate divisions. The head bears a pair of elbowed antennae composed of a long basal segment, the scape, and a terminal por- 
tion of several small segments, the funiculus (fig. 5). Sometimes the small segments of the funiculus are enlarged to form, at the extreme end of the antennae, a "funicular club" composed of one to four segments. Ants use their antennae constantly as "feelers," their olfactory organs being located primarily in the terminal segments. The eyes of ants are, in general, poorly developed. The worker and male castes have a pair of compound eyes, while the females have, in addition, three simple eyes or ocelli located on the top of the head (fig. 6). The thorax may be either

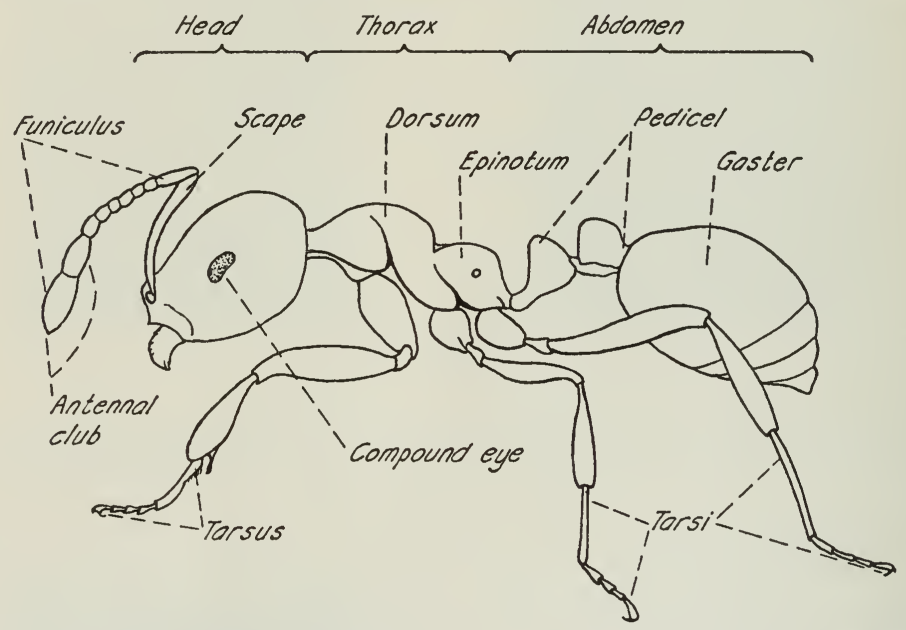

Fig. 5.-Diagrammatic drawing of an ant indicating the important structures used in this circular in the description of the different species.

long and slender, or robust, and is divided sharply into several immovable sections. Probably the most distinctive feature of the ant body is the manner in which the abdomen is attached to the thorax. The attachment generally consists of one or two slender segments, either round or bearing an erect or inclined projection or scale. This petiole or pedicel is a part of the abdomen, the remainder of which is known as the gaster. In some genera of ants the gaster is characteristically constricted behind the first segment. Another portion of the body often used to distinguish various forms of ants is the epinotum, the segment to which the petiole is attached. This segment may be rounded or may have a pyramidlike projection.

Ants within the same species vary considerably in form, the variations not being limited to three distinct castes ; each caste may be represented by one or more different forms. In some species the males are smaller than the workers, but more commonly are larger and have specialized 
mandibles. The queens are generally larger than the workers or males, but here again dwarfs and workerlike queens are represented in certain species. The workers, however, are more variable than the sexual forms, the size at times depending presumably on the amount of food received during their developmental period. Their heads vary greatly in size and shape, determined by the functions they are to perform in the social life of the colony. The head and mandibles of the soldier caste are very large, whereas the head of the typical worker is small, with variations in size between the two extremes. The head of a queen ant is usually small, while the thorax is larger than in the other castes of the same species.

Ants are generaily wingless except at mating time, when swarms of winged males and females that have recently emerged may be seen. After mating, the males soon die, whereas the females start separate colonies by their own efforts or with the aid of a few workers of the same species. The queens lose their wings soon after the nuptial flight.

Ants are often confused with the termites, which they resemble in many respects in their general form and social habits. Termites can be distinguished, however, by the following characteristics : Their antennae are like an open string of beads (moniliform), and are not elbowed as in ants. The mouth parts are fitted solely for chewing. The fore and hind wings, when present in the mating forms, are very similar in appearance, being long, narrow, and laid flat on the back when not in use. The wings extend far beyond the end of the abdomen. The abdomen is broadly joined to the thorax instead of being constricted as in ants ; and it bears, posteriorly, a pair of appendages, or cerci, which may be short or long, according to the species. The body of a termite has a much thinner covering than that of an ant, since the termite does not live under exposed conditions. Most termites are blind or have at best only vestiges of eyes. Their bodies may be either white or black, according to the form and the species. Termites feed on wood. Some species live in the wood and others in soil adjacent to wood or connected to wood by covered runways built by the insects.

Food and Nesting Habits.-The feeding habits of ants differ widely in the different species. Some depend solely on the bodies of insects or of smaller animals they can find or destroy. Some prey on other ants, and this habit has probably induced the practice of slave-making, typical of certain species. Many feed on the sweet exudations of plants or the saccharine excreta of insects; others on vegetable matter, seeds, and even fungi. One tribe of ants cultivate fungi in special chambers underground known as fungus gardens and tend the growing plants, and thus raise their own food supply. 
Nesting habits also vary with the species. The harvester ants gather seeds and stems of plants and earry them to their nests, which generally consist of fairly large mounds of soil and castoff material in the center of a cleared area. The tunnels of some species of ants may extend for some distance in the soil and many branch into galleries with small chambers in which the brood is reared. Many species construct simple nests under stones and logs, beneath the bark of trees, or in the foundations and walls of buildings. Temperature, moisture, and proximity to food supplies appear to be the chief factors controlling the selection of a nesting place for most ants.

\section{IDENTIFICATION OF SPECIES OF ANTS}

For the convenience of those readers who are technically trained in pest control, the following key is included for the identification of twenty-six of the more important ants in California which may be termed as noxious forms or which may be confused with them. The descriptions apply only to worker forms unless stated otherwise. Because of the very small size of most ants a strong hand lens or microscope will be needed in the use of this key. A 5-centimeter scale, as an aid in comparing measurements, appears at the head of this key. If the species is determined accurately, one can then select the appropriate control measures described herein by studying the food and nesting habits of the offending species. The more noxious forms, together with some of their habits and distribution, are further described in the text along with the control measures.

When there is occasion to send ants for identification they are best sent in vials containing a 70 per cent solution of alcohol. Dry specimens should be enclosed in a small box or bottle containing tissue paper, which prevents the ants from being broken in transit. The ants should never be mailed in envelopes, for then they become badly crushed and difficult to classify.

\section{Key to the Ants Discussed in This Circular}

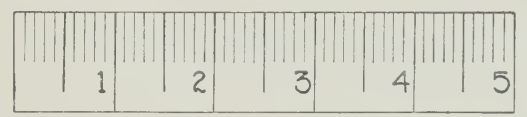

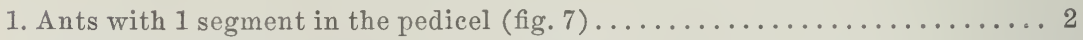
Ants with 2 segments in the pedicel (fig. 15) .......................

2. Anal opening terminal, circular, and surrounded by a fringe of hairs (fig. 26) .. 3 Anal opening not terminal, but ventral, slit-shaped, and not surrounded by a

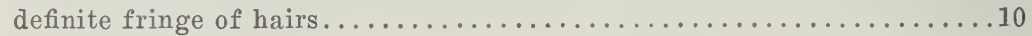




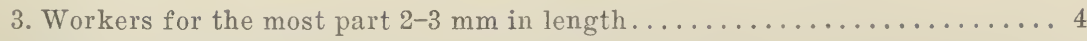

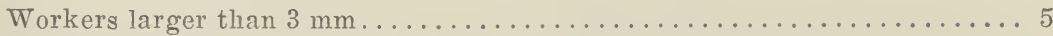

4. Thorax very narrow; gaster broader at the base (fig. 24) and coming to a sharp point. Prenolepis imparis var. californica Wheeler.

Thorax broader, not as abore. Lasius niger var. neoniger Wheeler.

5. Workers for the nost part smaller than $7 \mathrm{~mm} \ldots \ldots \ldots \ldots \ldots \ldots \ldots \ldots$

Workers for the most part larger than $7 \mathrm{~mm} \ldots \ldots \ldots \ldots \ldots \ldots \ldots \ldots \ldots$

6. Thorax and the head below the eyes distinetly rusty reddish; vertex (top) of head and abdomen black. Formica rufibarbis var. occidua Whecler.

Thorax not distinct in color from the abdomen but blending with abdomen. Formica cinerea Mayr., and its subspecies and varieties.

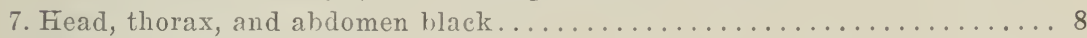

Thorax reddish or yellow . . . . . . . . . . . . . . . . . . 9

8. Legs, except tarsi, black. Camponotus levigatus (F. Smith).

Legs red. Camponotus herculeanus var. modoc Wheeler.

9. Thorax reddish; abdomen black. Camponotus maculatus vicinus Mayr., and its rarieties.

Thorax yellowish; first and second segments near pedicel usually yellow like the thorax. Camponotus maculatus maccooki Forel.

10. Epinotum with a pyranidlike projection (fig. 14) ................ 11

Epinotum without a pyramidlike projection....................... 12

11. Head and thorax blackish, blending with the dark abdomen. Dorymyrmex pyramicus Roger.

Head and thorax reddish; thorax definitely different from the black abdomen. Dorymyrmex pyramicus var. bicolor Wheeler.

12. Larger than $2.5 \mathrm{~mm}$. Thorax reddish; head reddish black; abdomen black and velvety. Liometopum apiculatum occidentalc Emery.

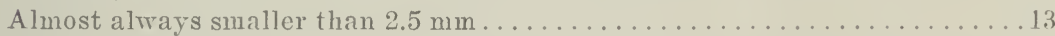

13. Petiole difficult to see, lying somewhat in a horizontal position and appressed closely against the overhanging abdomen (fig. 11). Tapinoma sessile Say.

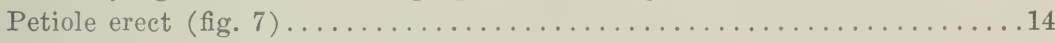

14. Brown, no odor on being erushed; walk in definite trails. Iridomyrmex humilis Mayr.

Yellowish brown, lighter than above, definite odor; do not ralk in definite trails. iridonyrmex analis (Ern. André).

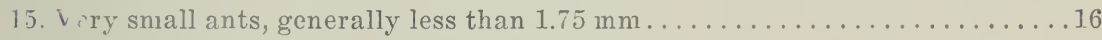

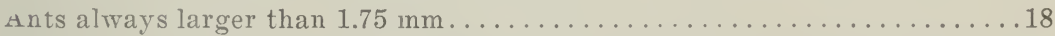

16. Antennae with 2-segmented club (fig. 16) ; red. Solenopsis molesta (Say), and its western variety validiuscula Emery.

Antennae with 3 -segmented club (fig. 18) . . . . . . . . . . . . . 17

17. Red. Monomorium pharaonis (Linn.).

Black. Monomorium minimum Buckley.

18. Pedicel inserted dorsally on abdomen (fig. 23). Abdomen heart-shaped, flattened dorsally, curved ventrally, and coming to a sharp point. Crematogaster spp.

Pedicel inserted terminally on abdomen (fig. 20) ................... 19

19. Antennae 11-jointed. Pair of spines on head; thorax with 3 pairs of dorsal spines or tubercles. Atta versicolor Pergande.

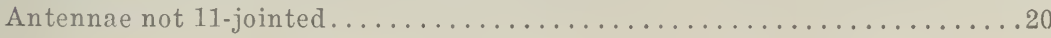


20. Antennae 10-jointed with a 2-segmented club (fig. 16); head and thorax shin-

ing red; abdomen black. Solenopsis xyloni var. maniosa Wheeler.

Antennae 12-jointed; antennal club, when present, with more than 2 joints.

21. Antennae with a 3 -jointed club (fig. 22).

Head with a deep furrow on vertex (fig. 22). Pheidole sp.

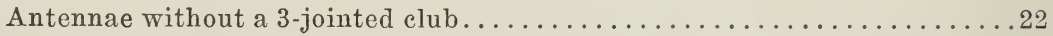

22. Smaller than $3.5 \mathrm{~mm}$. Blackish in color. Tetramorium caespitum (Linn.).

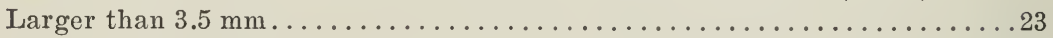

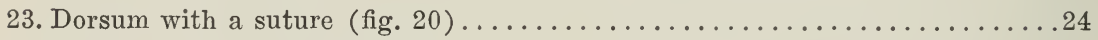

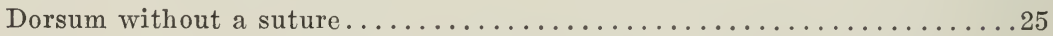

24. Thorax and petiole brownish; abdomen black. Veromessor andrei (Mayr.).

Thorax, petiole, and abdomen all shining black. Veromessor pergandei (Mayr.).

25. Posterior part of thorax without a pair of spines; bright red. Pogonomyrmex californicus Buckley, and its subspecies and varieties.

Posterior part of thorax with a pair of small spines; dark red. Pogonomyrmex subdentatus Mayr.

\section{CONTROL MEASURES}

General Considerations.-A study of the feeding and nesting habits of noxious ants aids one materially in selecting the measures needed for their control. Since queen ants are very prolific and give rise to an ever increasing horde to replace those that die through natural causes or are killed by accident or by designs of man, ultimate control must include the destruction of the queens rather than the more simple elimination of the offending workers. To accomplish this end, one must seek out the nests and apply such remedies as poisonous gases, solutions, and powders; or use poisoned baits that will destroy the ants and their queens when brought to them by the worker's. The innumerable places in which ants may build, the intricate architecture of some of their nests, their diverse food habits, and the facility with which they move their brood and queens to more favorable locations on the first approach of danger often make this task very difficult indeed.

Another factor that greatly hampers control is the ease with which ants may be spread from one location to another through the transportation of their nests or queens in nursery stock, manure, sod, or lumber, and by a variety of other means. Ants of themselves do not spread very rapidly, a factor that should facilitate their control.

The control measures for noxious ants may be divided into four general groups, based somewhat upon the food and nesting habits of the offending species. Many of the proprietary compounds that have been found satisfactory in the control of ants fit into one or more of these control divisions.

Precautions.-Since most of the poisons used in controlling ants are 
deadly to other creatures as well, they must be kept away from children and domestic animals. Keep all poisons properly labeled. A list of antidotes and emetics is given at the end of this circular for use in case poisons mentioned herein are taken accidentally.

Prevention and Repellents.-Measures that will prevent ants from having access to food materials or to nesting places where they will be difficult to control are to be recommended. Food in the kitchen and pantry should be kept in tightly covered containers, while drainboards and sinks should be kept free of food attractive to scouting ants that are forever lookir.g for a new supply. Ants may be kept from exposed food by surrounding the latter with water in a larger receptacle. The legs of tables and ice boxes may be placed in tins partially filled with water or light oil. Food boxes may also be suspended by wires protected by tanglefoot preparations or by repellents. Constant vigilance is necessary even under these conditions to keep ants from walking over dust-laden surfaces of such repellent materials.

Colonies of bees may be protected from ants by placing the hives on stands with the legs in cans partially filled with a light oil. Sometimes inverted metal cones are tacked to the legs of such stands, and the surfaces of the cones are painted with tanglefoot, renewed as necessary. Poison bait in ant tins placed in the vicinity of the hives will keep down the ant population where the nests cannot be found and destroyed, but care must be exercised to have the holes in the cans small enough to keep bees from gaining access to such poisons. Saturating the ground beneath the hives with crankcase oil discourages ants from building there. Carbolic acid solutions should not be used around beehives for controlling ants, for they are repellent to bees.

Sometimes ants gain access to dwellings by climbing trees or shrubbery in contact with the roofs or walls. Such invasions can be stopped by pruning back the branches and by setting out appropriate poison baits near the ant trails. (See "Repellents," pages 32-33.)

Contact Insecticides.-To eliminate an invasion of ants temporarily it is sometimes expedient to use oily or corrosive sprays that kill the ants when brought in contact with their bodies. These measures afford temporary relief only; they have no lasting effect on the colony population. Contact poisons are most effective at swarming time when the many queens can be killed, or when the entire colony may be forced to move by rain or irrigation water. Queens of the Argentine ant frequently travel with the workers during the fall and winter periods and the population of a colony may be effectively reduced by contact sprays at such times. (See "Contact Insecticides," page 33.) 
Fumigants.-Where fumigants can be introduced into ant nests without endangering other animal life or growing plants, an efficient application will exterminate the entire population, including the queens and developing stages. This is the only positive means of eradication. It kills the colony at its source-the queens; and the workers that are not killed will soon die. (See "Fumigants," pages 34-35.)

Stomach Poisons.-These poisons are generally used in two different media: in sugar sirup and honey for sweet-loving ants and in grease or fats for fat-loving ants. The ideal poison is one that will either kill or affect the workers so slowly that they will carry it into their nests to poison the queens and brood. Most poison baits, however, simply reduce the populations temporarily and then must be used again periodically when the colony strength is regenerated. (See "Stomach Poisons," pages $35-37$.)

\section{DESCRIPTION AND CONTROL OF THE COMMONER ANTS IN CALIFORNIA}

\section{THE ARGENTINE ANT}

General Distribution. - The Argentine ant, Iridomyrmex humilis Mayr., first observed in New Orleans in 1891, was supposed to have been introduced on ships arriving from Brazil. It has been spread rapidly by various agencies and was first collected in California in 1905, probably near Ontario, by E. S. G. Titus. In 1908, after identification of this pest was definitely made, colonies were found established at Alameda, East Oakland, San Francisen, San Jose, and at a point near Campbell; and in southern California it was located by Professor H. J. Quayle in Los Angeles, Azusa, and Upland. By 1910, it had occupied about 5,000 acres in the state and by 1916 had become established in 16 separate localities. Since then the Argentine ant has become generally distributed throughout the state at the lower altitudes in moist situations around residences and in orchards. The cost of controlling this pernicious species is continually mounting, as is the amount of damage attributed to it.

Description.-The workers of the Argentine ant are 2.2 to $2.6 \mathrm{~mm}$ (millimeters) in length when the abdomen is not distended with food. They are brown, with the thorax, scapes, and legs somewhat lighter. The mandibles are yellowish and characteristically dentate (fig. 6). The queens are larger and more robust than the males. No perceptible odor is produced on crushing individual specimens of this ant, but when large numbers are crushed, a characteristic musty or greasy odor is noticeable. This ant always works in definite trails.

The Argentine (fig. 7) ant is often confused with the odorous house 
ant, Tapinoma sessile, also a common, sweet-devouring household pest that moves in trails. The odorous house ant is blacker, slower, and more squat, with a broader abdomen; upon being crushed it gives forth a

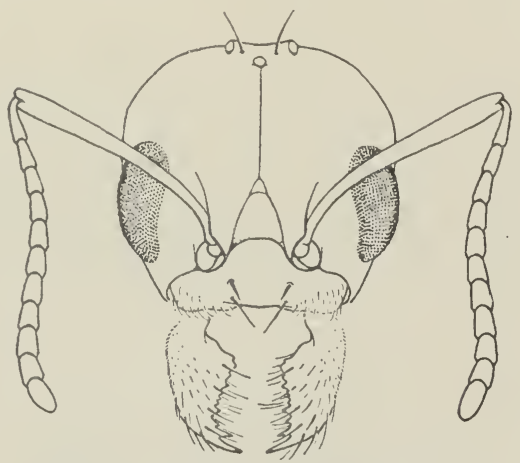

Fig. 6.-Head of the Argentine ant, showing the characteristic arrangement of the teeth and the elbowed antennae. The small eyes at the top of the head distinguish the queen from the worker. (From Bul. 207.)

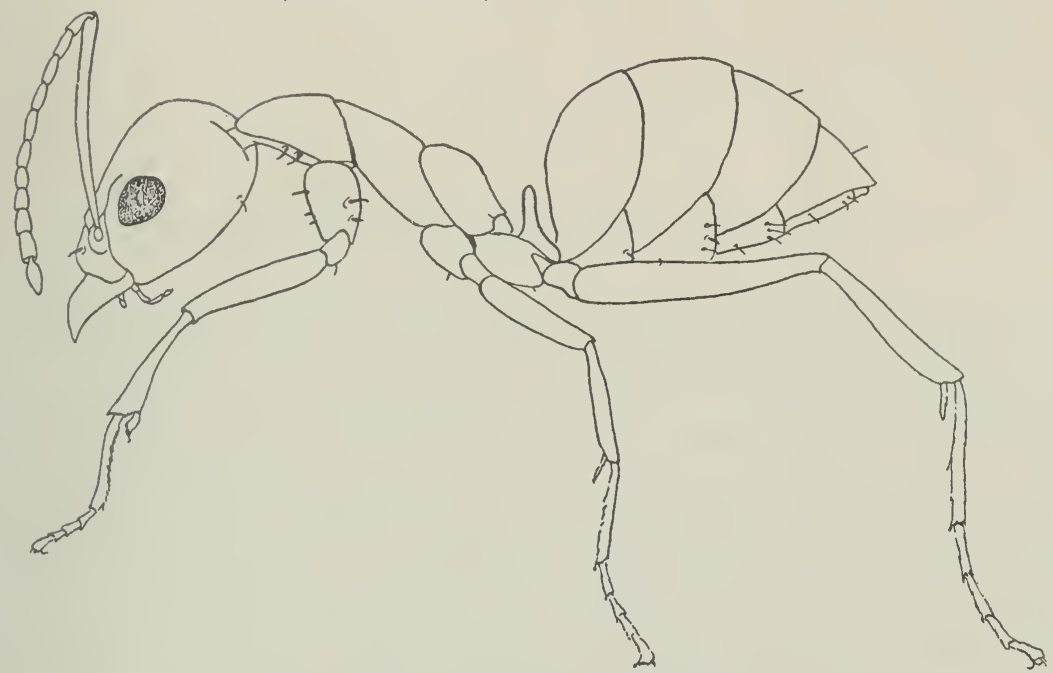

Fig. 7.-The Argentine aut, greatly enlarged. This is the most important ant pest in California. (From Cir. 38.)

more pungent odor. Another ant, Iridomyrmex analis (fig. 8), closely resembles the Argentine in structure; it differs, however, in being much paler-colored, having a noticeable odor, and not confining its foraging to distinct trails.

Nesting Habits.-Nests of the Argentine ant are situated wherever 
sufficient moisture is available and wherever light is excluded, both insicle the house and outside in the garden or orchard. Within the nest are numerous queens that show no antagonism to one another. Mating takes place in the nest and nuptial flights are as rare as are the winged females. The queens are very prolific, laying eggs in enormous numbers. The rate of egg production and the time necessary for the completion of the egg, larval, and pupal stages all vary greatly with temperature, moisture, nutrition, and other factors. The time from the egg to the adult has been observed to vary from 33 to 141 days, with an average of 74 days.

In California these ants begin to increase toward the end of February,

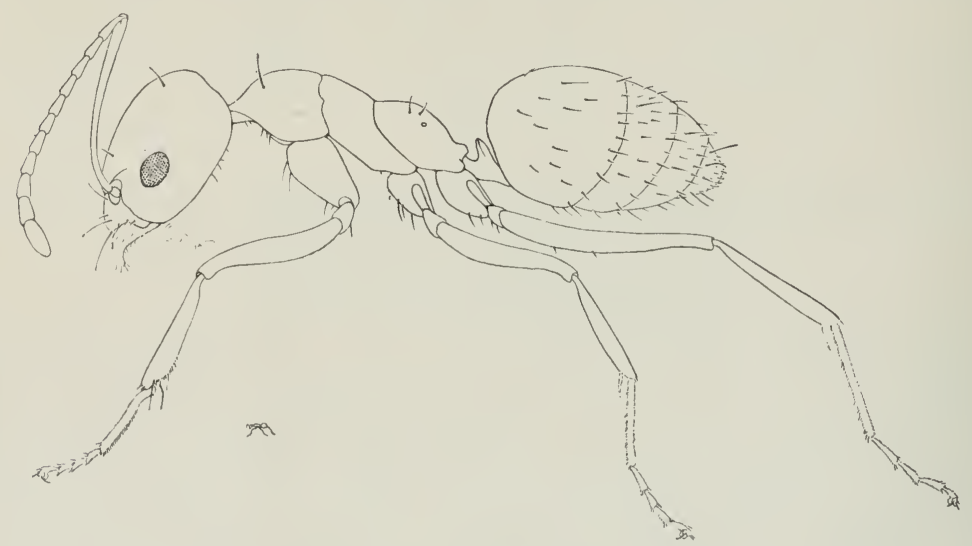

Fig. 8.-Worker of Iridomyrmex analis. (From Bul. 207.)

reach their maximum numbers during July, August, and September, and decrease about the middle of October. During the winter they congregate and form large colonies in limited areas, the favorite nesting places being under hedges in leaf accumulations; in the ground, where they penetrate to a depth of 6 inches; and in manholes or basements kept warm by steam pipes. Hundreds of queens may be present in such localized colonies. During the spring and summer the ants gradually spread out over larger areas, particularly along the edges of walks, under shrubbery, and in other situations kept well moistened. At such times the nests are usually from $1 / 2$ to $1 \frac{1}{2}$ inches below the surface of the soil.

Argentine ants are a nuisance in the household because they invade the cupboard and intermingle with all the provisions therein, being particularly fond of such sweets as sugar, honey, and cake.

In the garden and orchard they faithfully tend and protect such "antcows" as aphids, mealybugs, and scale insects for the honeydew excreted by these insects. Since the ants effectively force parasites and predators 
of these insects to keep their distance, the "ant-cows" increase beyond their normal numbers and greatly injure the vegetation on which they feed. The control of aphids, mealybugs, and scale insects, therefore, is directly involved in the control of their efficient bodyguards, the Argentine ants.

Control.- The Argentine ant can be reduced or exterminated only through continuous and unrelenting efforts that match the ants in persistence. As stated previously, control should be directed against the queens, for relief can be expected only where the queens are either exterminated or greatly reduced in numbers. As many observers have noted, control is easiest in the spring or autumn, the problem being somewhat more difficult during midsummer because then the colonies are stronger and more scattered and because the honeydew of the aphids, mealybugs, and coccids acts as a counter attraction to the poison baits.

One may definitely control the Argentine ant by pouring carbon disulfide $^{4}$ (page 34), cyanide ${ }^{5}$ (pages $34-35$ ), kerosene-pyrethrum (formula 3 ) or kerosene (page 33) into their nests after first perforating the latter with a pointed implement. A solution of pyrethrum and soap (formula 7 ) should be used where vegetation is abundant. The direct application of fluids is usually feasible only in small areas, as around the foundations of a house and in the garden, since the nests are usually small, numerous, and hard to find. Since the Argentine ant prefers situations where leaves have accumulated, leaf debris must be removed.

At times, particularly during the summer, when the ants are widely distributed throughout an infested area, direct application of liquids may not be feasible. Recourse must then be made to sweetened poison baits upon which the ants will feed and which they will later carry to the queens and the larvae in the nest. Thus through the slow poisoning of the workers, queens, and young, effective control may be realized in a relatively short time.

The government Argentine ant formula (formula 8) and the modified ant sirup (formula 9) are effective in controlling this ant. Sodium arsenite is a deadly poison and when used, should always be placed outside dwellings, and away from small children and domestic animals. The poison baits should be put in suitable receptacles, containing several strands of excelsior, and then placed near the ant trails. Cans should be distributed every few feet, particularly near the foundation of the house or in the orchard where the trails of ants are most commonly found.

${ }^{4}$ Carbon disulfide is highly explosive when brought in contact with a flame.

${ }^{5}$ Cyanide is an extremely poisonous compound and particular care should be exercised to prevent any person or domestic animal from breathing its fumes or getting it into the mouth. 
These cans should be cleaned and refilled with poison sirup every 5 to 10 days. Since in time the sirup may harden through evaporation and become unattractive to the ants, the cans should be cleaned and the excelsior replaced every 3 or 4 weeks. All the cans should be set out at one time so that the effect of the poison on the ants will be intensified as quickly as possible. The speed and the effectiveness with which the ants are controlled often depend upon the number of cans distributed.

The control of ants by the use of poison baits is seldom immediate, generally extending over a period of days or even weeks. If the ants do not visit the cans, the location of the cans should be changed. But if the ants continue to visit the baits in diminishing numbers, control is being effected and the poison should be replenished as indicated above.

Often the ants will make their shallow, loose, earthy nests directly under the cans; if this happens, the cans should be moved to different locations and such nest sites wetted with kerosene or any other soil insecticide.

Only rarely are all the queens exterminated; therefore the ants, after 2 to 6 months, may multiply to their former numbers. There is little likelihood of this occurring if the cans are kept filled with poison.

Ants may change their path of travel after a number have been killed off by a poison bait and so it is advisable to change the location of the cans as soon as this situation occurs.

Whenever the ants are found nesting in cracks inside a house, cotton wads saturated with a mixture of ethylene dichloride and carbon tetrachloride (formula 6), or with the kerosene and pyrethrum mixture (formula 3 ) or with kerosene alone, and inserted in several places along the fissure, will often force the ants to leave. An atomizer or oilcan may be used to force these materials into the crevices. Ordinary fly spray is useful for the prompt extermination of ants entering the house.

Chemicals like pyrethrum, rotenone, sodium fluoride, naphthalene, and paradichlorobenzene may be spread where ants make their entrance into a room or where the ants have their trails and will prove effective as long as the chemicals are active or until the ants find a way through or around the dust barrier. Borax has not been found effective against the Argentine ant but a combination of borax and sugar, thoroughly mixed, causes the death of ants that attempt to eat the sugar. Nicotine sulfate used as a spray on plants for aphids often repels ants in general.

Tartar emetic sirup (formula 12) is not very effective against the Argentine ant, being slow in its action, but it may bring some control after 5 or 6 weeks. The use of tartar emetic placed in cans is advisable in dairies, groceries, and other places where food is merchandised. One may 
control the ants entering such establishments by distributing poison baits outside the building.

Where ants are to be controlled over large areas (for example on school grounds) where there are many buildings, and where the number of cans and the amount of labor to be expended is limited, the cans, instead of being widely distributed, should be concentrated about the chief source of infestation; and by intensifying the poison campaign at this point, one is often able to control the pest. Then the cans should be moved on to the next center, and the campaign concentrated there in a like manner.

Control in orchards may be effected with the Argentine ant formula (formulas 8 or 9 ). Four-ounce baking powder tins (fig. 9, $D$ ), with opposite sides indented to permit the entrance of ants, can be used for this purpose. The bait cans should be distributed as frequently as the ant population warrants, one can per tree, if necessary, and then moved to another portion of the orchard as soon as control in one area is effected. The cans may be attached to stakes or directly to the trees. A shade board over the cans will tend to decrease evaporation of its contents. Where the orchards are irrigated the ants may be found to nest around the base of the tree and may be killed in great numbers by fumigants or powders not injurious to the trees.

Because of the danger of children or animals overturning the cans, the cans and lids should be attached by some such means as shown in figure $9, A, B$, and $C$, and located as inconspicuously as possible. A method of making the lids of cans difficult to remove is as follows : a piece of wire is passed through two small holes in the lid to form a closed loop (fig. 9, $A)$; holes are bored through the can on opposite sides so that a serew can be passed through it with the wire from the lid under the screw (fig. 9, $B$ ) ; and the screw is then inserted into a stake, wall, or tree.

Poison cans should be waterproofed with paraffin of a high melting point (above $124^{\circ} \mathrm{Fahrenheit).} \mathrm{In} \mathrm{each} 4$-ounce paraffined can (fig. 9, $D$ ) a few loose strands of excelsior are placed, and then the sirup is poured in until the container is one third to one half full. Before being paraffined, the cans should have a hole punched in them near the top of one side, by means of which the can may be nailed to the tree or stake, preferably where the ants are most numerous.

A more efficient system than the use of excelsior is to pour a thin layer of paraffin over the ant sirup in the tin. If this layer of wax is then broken from the sides of the tin, it will act as a float for the ants and will prevent excess evaporation of the contents of the can. It can be used again each time the can is refilled. 

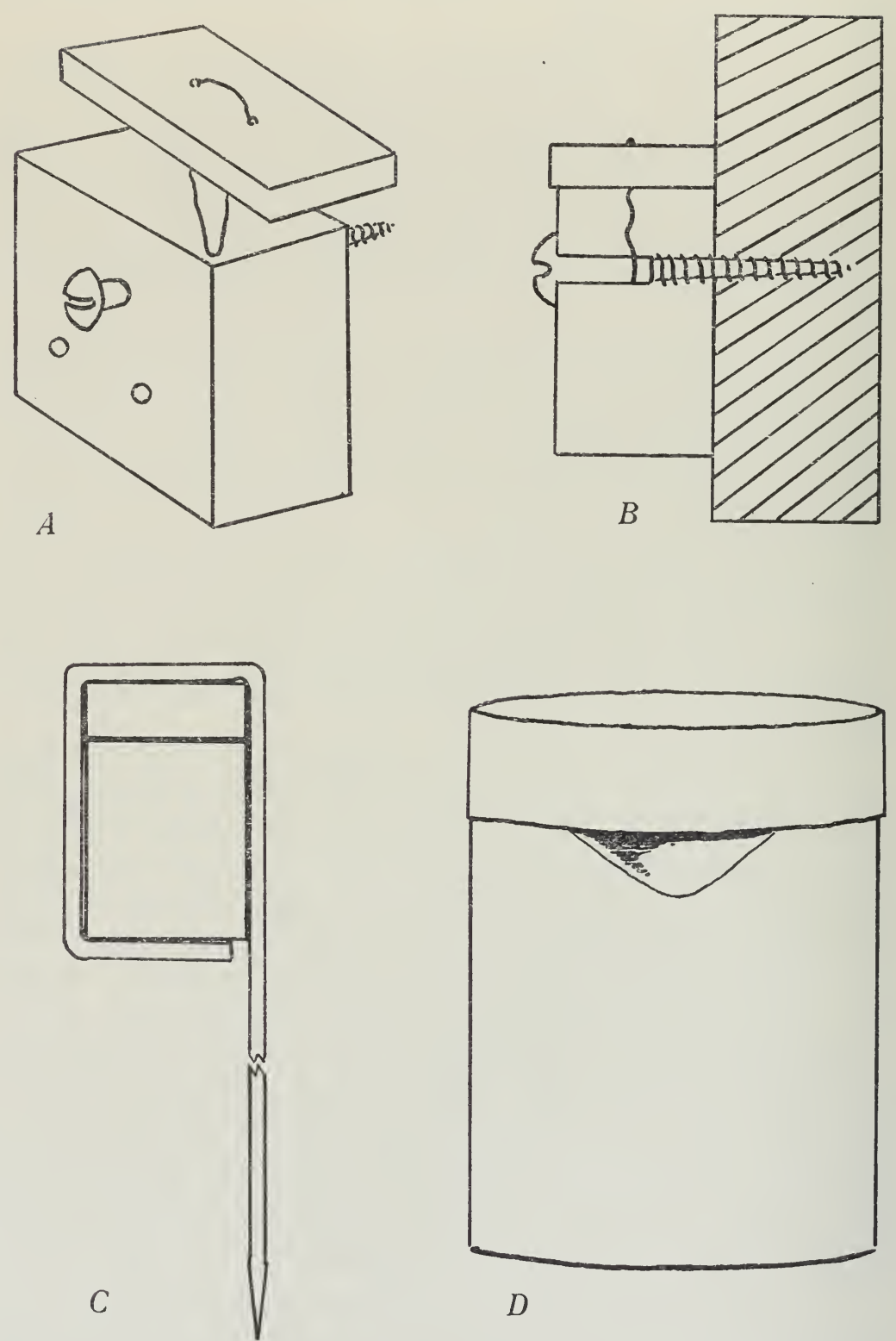

Fig. 9.- $A, B$, One method of making the lids of cans fast so that children cannot readily remove them; $C$, a wire stake that may be used to fasten cans to the ground; $D$, an ordinary baking powder tin with an indented side makes an excellent poison can. 


\section{THE ODOROUS HOUSE ANT}

This small black ant, Tapinoma sessile Say (figs. 10 and 11), is distributed throughout the United States from sea level to 10,000 feet and ranks second only to the Argentine ant as a house pest. It is 2 to $3 \mathrm{~mm}$

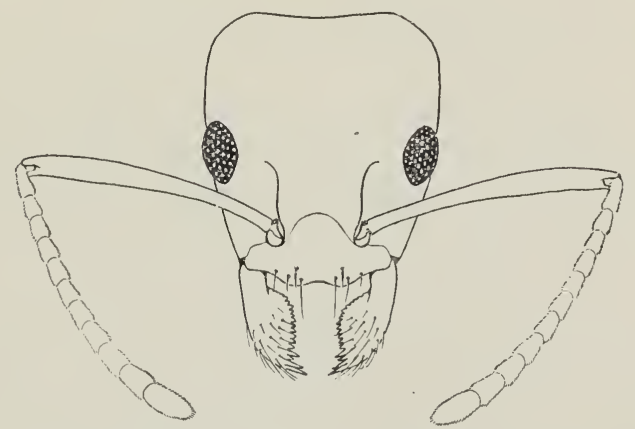

Fig. 10.-Face of the odorous house ant. This species of ant is most commonly confused with the Argentine ant. Note particularly the arrangement of the teeth on the jaws. (From Bul. 207.)

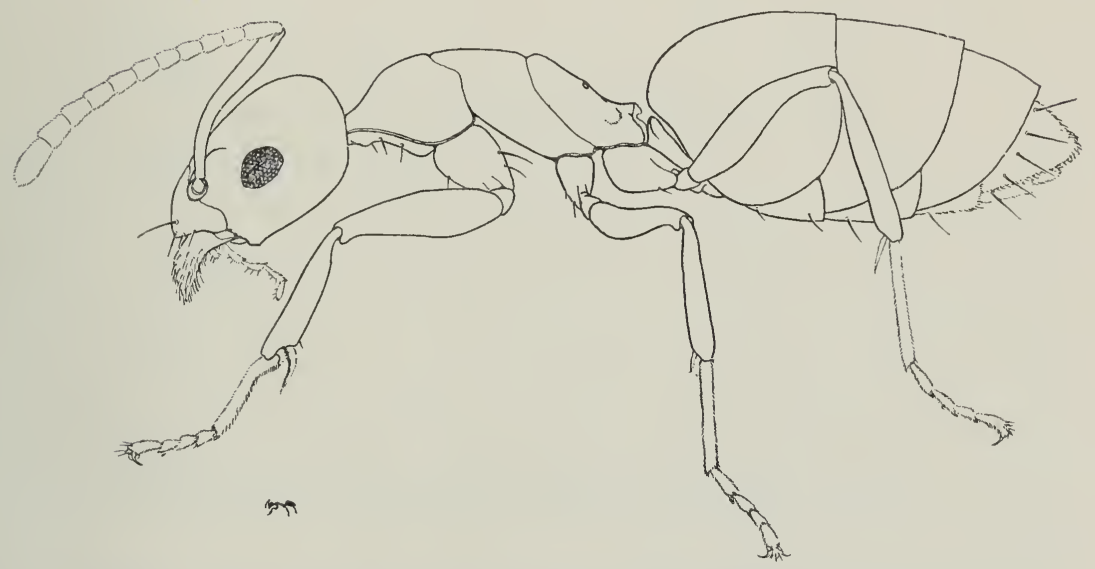

Fig. 11.-Worker of the odorous house ant. Note how the top of the abdomen overhangs the "petiole." (From Bul. 207.)

long and may be readily distinguished from the Argentine ant (which it superficially resembles) by its darker color, by its odor upon being crushed, and by the fact that the overhanging abdomen apparently hides the petiole, which is readily seen in the Argentine ant. This sweet-loving ant travels in trails, often invades the kitchen, and may be found nesting 
in crevices between the walls, sills, or floors. In the orchard it is fairly important because of its habit of tending aphids. It commonly occurs in apiaries, where large colonies often may be found beneath the top or inner covers of a hive. There, however it is probably of little consequence; it nests in the hive apparently because of the warmth given off by the colony rather than because of proximity to a food supply.

Control may be accomplished by methods listed for the Argentine ant.

\section{THE CALIFORNIA VELVETY TREE ANT}

The worker of this ant, Liometopum apiculatum occidentale Emery (fig. 12), is 2.5 to $6 \mathrm{~mm}$ in length, with a glistening velvety-black abdo-

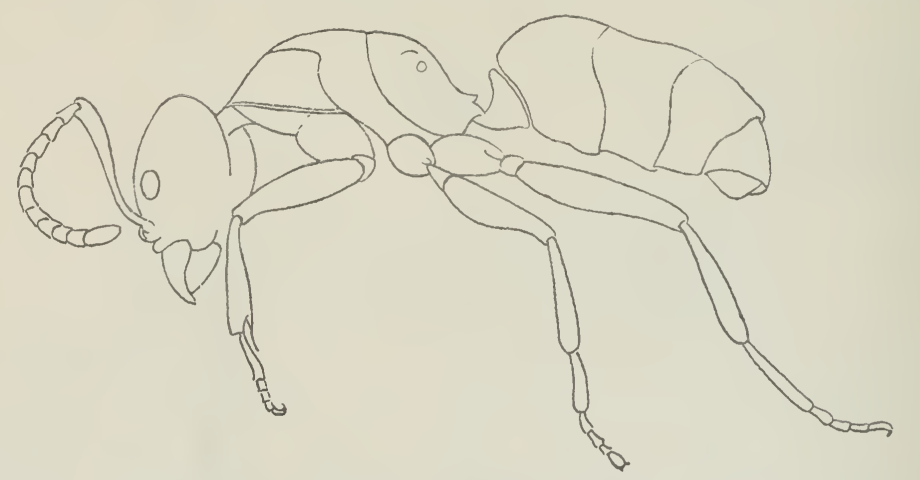

Fig. 12.-Worker of the California velvety tree ant.

men, a red thorax, and a brownish-black head. These ants are found in the foothills and mountains throughout the state. They are exceedingly common in the San Joaquin and Sacramento valleys, where they range up and down oak, alder, elm, cottonwood, and other trees in or'der to tend aphids. Their trails may extend 200 feet or more from the base of the tree or $\log$ where they nest. Houses are subject to invasion not only for sweets but also for insects. The ants generally make their forays in dwellings at dusk or during the night, although many searchers may be present during daylight hours. The queens have been found nesting beneath rocks and fallen timber.

Control may be secured by placing five or six cans containing the Argentine ant poison (formula 8 or 9 ) at the base of each tree or post where ants occur in the greatest numbers. Although this poison kills rather slowly, it more or less limits the forays to the vicinity of the cans. A mixture of pyrethrum and sodium fluoride (formula 11) distributed around the base of the tree at the rate of $1 / 2$ pound per tree will effectively keep them from climbing thereon for about 5 days; and not only 
will this mixture kill many of the ants, but it will often force them to move their nests elsewhere. The powder should completely encircle the base of the tree, and some of it should be sifted a foot or more up the trunk. This mixture may kill all the vegetation to a distance of 6 inches

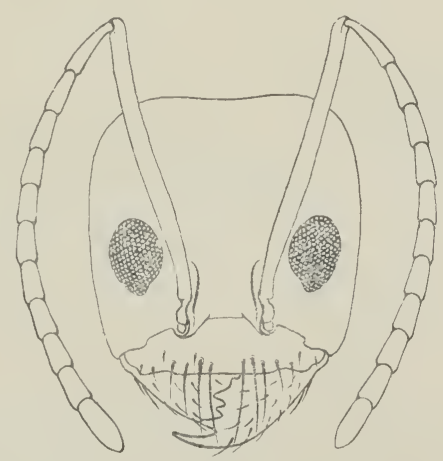

Fig. 13.-Head of Dorymyrmex pyramious. The coarse teeth on the jaws are very characteristic of this ant. (From Bul. 207.)

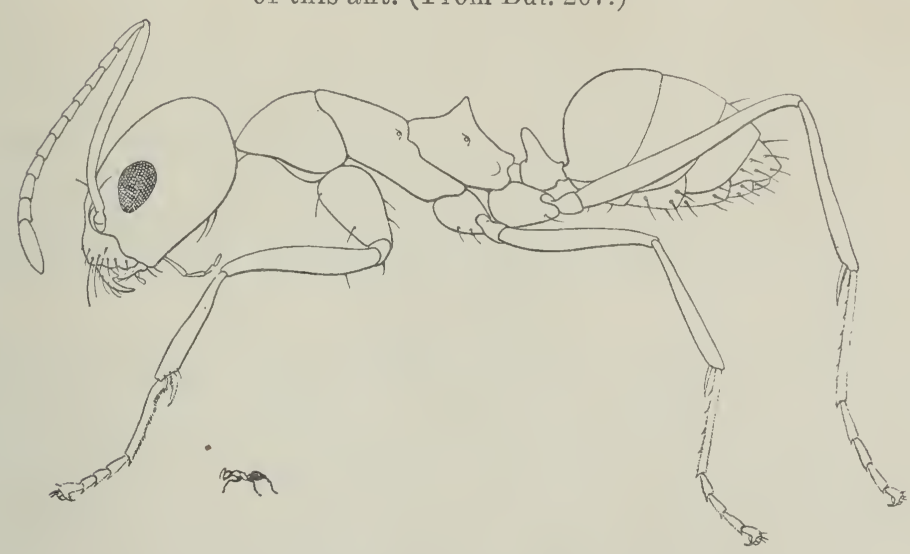

Fig. 14.-Worker of Dorymyrmex pyramicus. Notice the pyramid above the base of the middle and hind legs. (From Bul.207).

from the tree base. After 5 days the powder will have to be renewed. Tree surgery to remove decayed portions in which the ants nest will aid in eliminating this pest.

\section{THE PYRAIMID ANT}

The pyramid ant, Dorymyrmex pyramicus Roger, is relatively common at the lower altitudes throughout California. It is small, 1.5 to 2.0 $\mathrm{mm}$ in length, with a reddish-black head and thorax and a black abdomen. 
The head features and the pyramidlike projection on the thorax are distinctive (figs. 13 and 14). It nests predominantly in dry, vegetationfree areas. In southern California it sometimes invades dwellings.

Best control is obtained with such soil fumigants as kerosene, carbon disulfide or a mixture of kerosene and pyrethrum (formula 3) poured into nests in the manner previously described for the Argentine ant. Poison sirups are also effective.

\section{THE BICOLORED PYRAMID ANT}

The bicolored pyramid ant, Dorymyrmex pyramicus var. bicolor Wheeler, is slightly larger than the pyramid ant, has a red head and thorax. In habits and distribution it resembles the pyramid ant. It is of negligible economic importance.

\section{THE CALIFORNIA, OR MEXICAN, FIRE ANT}

Description.-This fire ant, Solenopsis xyloni var. maniosa Wheeler, one of the most serious ant pests in California, is distributed at lower altitudes from southern California up through the Sacramento Valley. The worker (figs. 15 and 16 ) is 1.6 to $5.8 \mathrm{~mm}$ in length, with a yellowishred head and thorax and a black abdomen. The females are about 6.6 $\mathrm{mm}$ in length, light reddish brown with a black abdomen; the males are reddish black with reddish-yellow legs. The males and females may be observed throughout the year, particularly on warm days, moving actively on the surface of the ground, most commonly from June to September. These winged forms are often observed in enormous numbers in store windows.

The California fire ant is the only common fire ant known to oceur in California; it is generally distributed throughout Arizona and New Mexico. In the field these ants dwell under boards.and stones and in fissures in the soil as well as in cracks in sidewalks, where they generally construct flattened and irregular craters of thrown-up soil. When disturbed by other ants they raise and vibrate their abdomens peculiarly. Being very pugnacious, they will rush from the nest and bite and sting upon the slightest provocation. They are important pests because they invade houses, steal seeds, feed upon plants in both greenhouses and orchards, tend aphids and mealybugs, feed on fatty foods, and gnaw holes in clothing. Their sting causes a burning sensation, hence the name "fire ant." They frequently destroy almonds that have fallen to the ground. In citrus orchards they are known to remove bark from young trees and to feed upon the cambium layer. This ant is also known to be destructive to ground-nesting bird life, and especially to quail. They 
invade the nest, harass the mother bird until she may desert the nest, and attack and kill the chicks as soon as the eggs are pipped or while the chicks are still wet after emerging. Through these attacks the bird population of an area in which the ants abound may be greatly reduced. Similar losses of baby chicks have been reported by poultrymen.

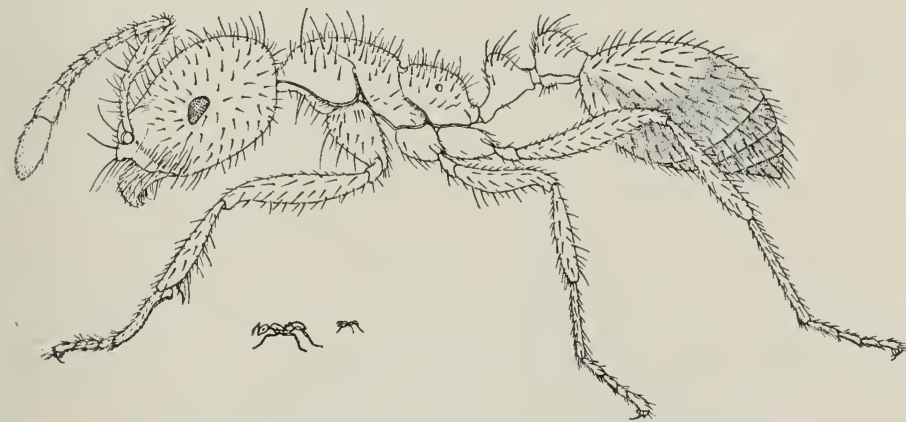

Fig. 15.-Worker of the California fire ant. The small figures show the difference in size between the largest and smallest workers of this ant. (From Bul. 207.)

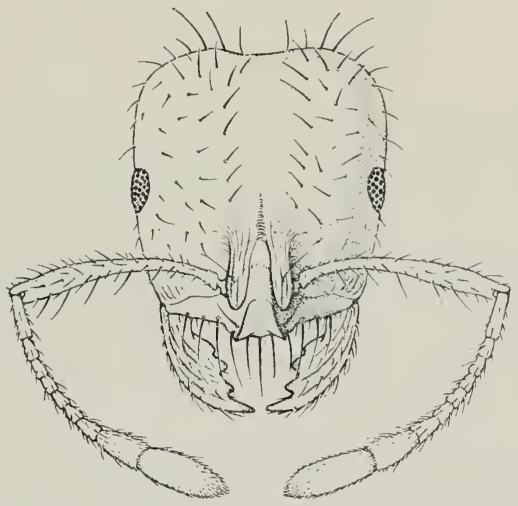

Fig 16.--Head of the California fire ant. The 2-segmented antennal club is characteristic of this species. (From Bul. 207.)

Control.-These ants may be controlled over small areas by pouring kerosene, or carbon disulfide, into their nests. They may be effectively controlled in lawns by sprinkling a liberal amount of pyrethrum over the nest and covering the area to confine the fumes.

Control in orchards and greenhouses is sometimes effected through the use of sodium arsenite sirup (formula 8 or 9). One or two grams of powdered arsenic, however, thoroughly mixed with 100 grams of ground- 
up walnut meats or rubbed into bacon strips (formula 10) has often been effective. When these ants invade the kitchen and feed on cereals, their numbers may be reduced by preparing a poison using 100 grams of the cereal to 1 or 2 grams of sodium arsenite. This bait should be placed in appropriately labeled ant tins where the ants occur. In such cases the nests of these ants will generally be found in the ground outside the house. Calcium cyanide applied to the nest is very effective. The dust should be laid down in a thin layer over the surface of the soil and cov-

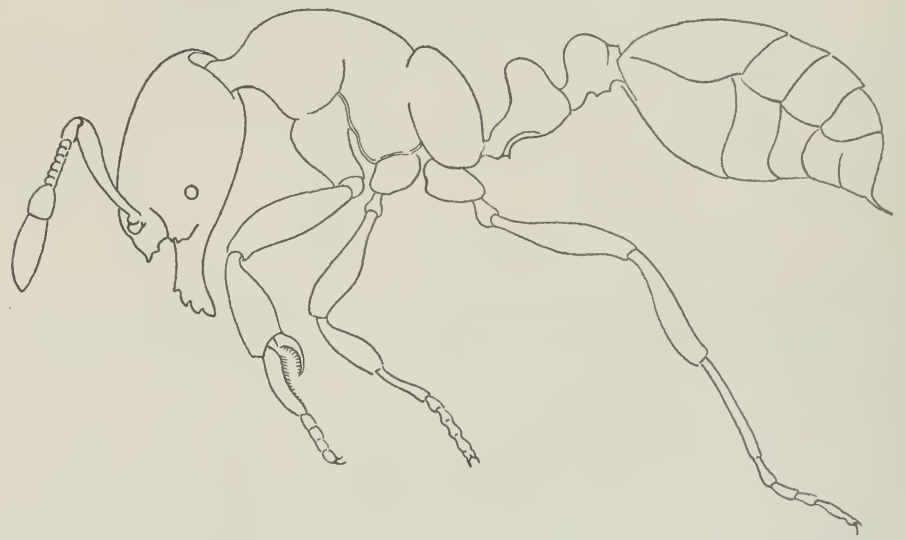

Fig. 17.-Worker of the western thief ant. This tiny ant is very often an important pest in the home.

ered; it should not be mixed with the soil if the nest is within 5 feet of the base of the tree. Other soil fumigants may be used as listed under Argentine ant control.

\section{THE WESTERN THIEF ANT}

These tiny yellowish ants, Solenopsis molesta var. validiuscula Emery (fig. 17), are approximately 1 to $1.5 \mathrm{~mm}$ long. They may be distinguished from Pharaoh's ant, which they superficially resemble, by their smaller size, by their lighter color, and by the antennae having a 2-jointed club rather than a 3 -jointed club.

Although, in the West, these ants normally live in the fields, they may invade and nest in or under houses, where they become pests of great importance. Sweets do not attract them; they are usually found feeding on grease, other animal matter, and cheese. Often they feed upon dead rats and mice, and thus might convey disease-producing organisms to human food. They are a source of great trouble in poultry houses, where they attack young chicks. Because of their small size they are not easily kept from any container in which food is stored. 
Control.---Effective control has been obtained by using bacon strips into which a small quantity of arsenic (about a pinch) has been rubbed thoroughly (formula 10). The bacon is then distributed in ant cans. It should never be exposed where animals and children might get it. Such materials as powdered derris, fresh pyrethrum, or a mixture of sodium fluoride and pyrethrum (formula 11), spread near the source of infestation, will often repel or kill these ants. Care must be used in the handling of sodium fluoride as this compound is too poisonous to be distributed haphazardly in the kitchen.

Since these ants nearly always nest in crevices, liquid materials such

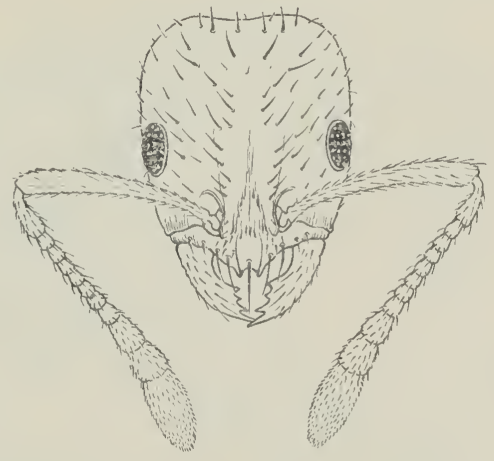

Fig. 18.- - Head of Monomornum sp. This tiny ant is often a house-invading ant. (From Bul. 207.)

as kerosene, a mixture of kerosene and pyrethrum (formula 3), or a solution made of ethylene dichloride and carbon tetrachloride (formula 6 ), may be put into the crevices by means of cotton wadding or injected with a syringe or oilcan.

\section{PHARAOH'S ANT OR THE LITTLE RED ANT}

Pharaoh's ant, Monomorium pharaonis (Linn.), is light yellow in color and about $1.5 \mathrm{~mm}$ long. Its nests are to be found in crevices in the walls and floors of the house as well as in the garden or lawn. Each nest usually contains two or three very fertile queens which, in heated houses, may breed throughout the year. These ants are not so common in the West as in the East. They feed readily on sweets and are particularly fond of greasy materials. They may be distinguished from the thief ant by the three segments in the antennal club (fig. 18) as compared with the two-segmented antennal club of the thief ant. The thief ant, furthermore, confines itself more closely to greases in its feeding.

Control.-A mixture of sodium fluoride and pyrethrum (formula 11) 
has successfully controlled the Pharaoh's ant; the material is scattered where the ants occur most commonly. Powdered derris and sodium fluosilicate also prove effective when scattered in dust form. These materials are poisonous to ants and retain their repelling effect for several days. A pinch of sodium arsenite rubbed into bacon strips may be used as a control for them as for the western thief ant. Ants in crevices may be controlled by the same fumigants as listed for the western thief ant.

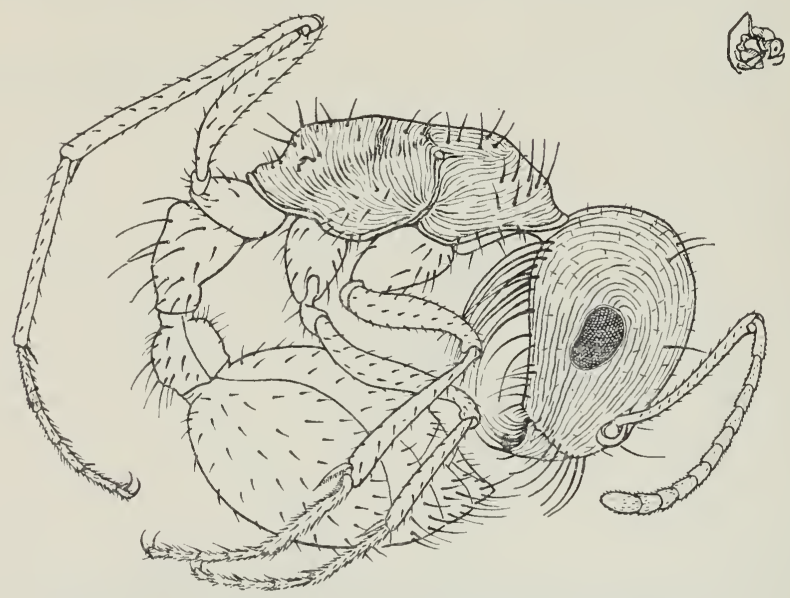

Fig. 19.-Worker of the California agricultural ant, Pogonomyrmex californicus. These ants often coil themselves up as shown, when picked up. Note the long hairs on the underside of the head. (From Bul.207.)

THE TINY BIACK ANT

This jet-black ant, Monomorium minimum Buckley, is slightly smaller than Pharaoh's ant, being but 1 to $1.5 \mathrm{~mm}$ long. It is distributed throughout the United States. The nests are often found beneath rocks, in lawns, or in areas free of vegetation, where their presence is betrayed by the very tiny craters of fine soil. Though not nearly so much a house ant as Pharaoh's ant, the tiny black ant does often invade dwellings in search of sweets and greases. The control methods listed for the Pharaoh's ant may be used for this species.

\section{THE AGRICULTURAI OR HARVESTER ANTS OF THE GENUS POGONOMYRIMEX}

California has a number of agricultural ants, sometimes important because they clear large areas of plant growth about their nests. Also when disturbed near their nests, these ants sting viciously. They inhabit chiefly arid areas. The long hairs (fig. 19) which extend from the so- 
called "chins" of these ants and their reddish color are characteristic of both species.

The California agricultural ant, Pogonomyrmex californicus Buckley, is the most common agricultural ant in California. It is from 5.5 to $6 \mathrm{~mm}$ in length with the body color a light rusty red; the mandibles, clypeus, and legs are more yellowish. There are no spines on the thorax.

The small-toothed agricultural ant, Pogonomyrmex subdentatus Mayr., widely distributed throughout California, is an attractively colored ant about $6 \mathrm{~mm}$ in length of a dark wine-red color. It is rarely of economic importance.

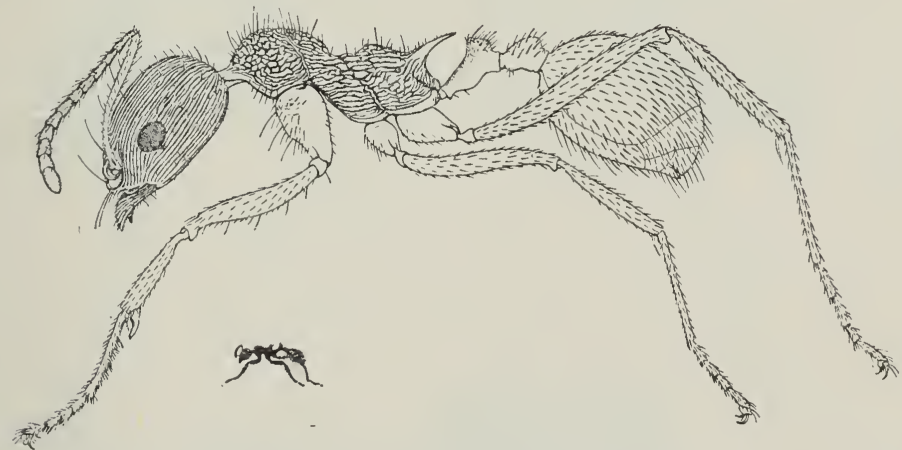

Fig. 20.-Worker of a black harvester ant, Veromessor andrei. Note the position of the thoracic spines (only one of which is shown) and that the pedicel is attached terminally. (From Bul. 207.)

Control.-Carbon disulfide has been successful in the control of the agricultural ant. About 4 ounces is applied to each nest in one of the following ways :

1. Expose the several tunnels of the nest by removing the top layer of soil to a depth of about 6 inches, pour carbon disulfide in the tunnels and over the surface of the ground, and replace the soil.

2. Pour the liquid directly in the exposed entrances without disturbing the nests; then cover the holes with earth.

3. Pour the carbon disulfide into a shallow pan on top of the nest, and cover the entire mound with a metal tub or wet canvas, the edges of which should be banked with earth. Cover with soil any portion of the nest not covered by the tub or canvas.

For better results, repeat the application after one week. Because of the fierceness with which these ants sting, boots should be worn while digging around the nests.

Control may also be effected with the use of calcium cyanide powder or a solution of sodium cyanide in water, as described on page 34 . 


\section{THE AGRICULTURAL OR HARVESTER ANTS OF THE GENUS VEROMESSOR}

The black harvester ant, Veromessor andrei (Mayr.), shown in figure 20 , is 4.5 to $7 \mathrm{~mm}$ in length, with a reddish-black thorax; in some specimens the posterior part of the abdomen is black. This ant is almost entirely limited to California in its distribution, being most common in the southern part of the state.

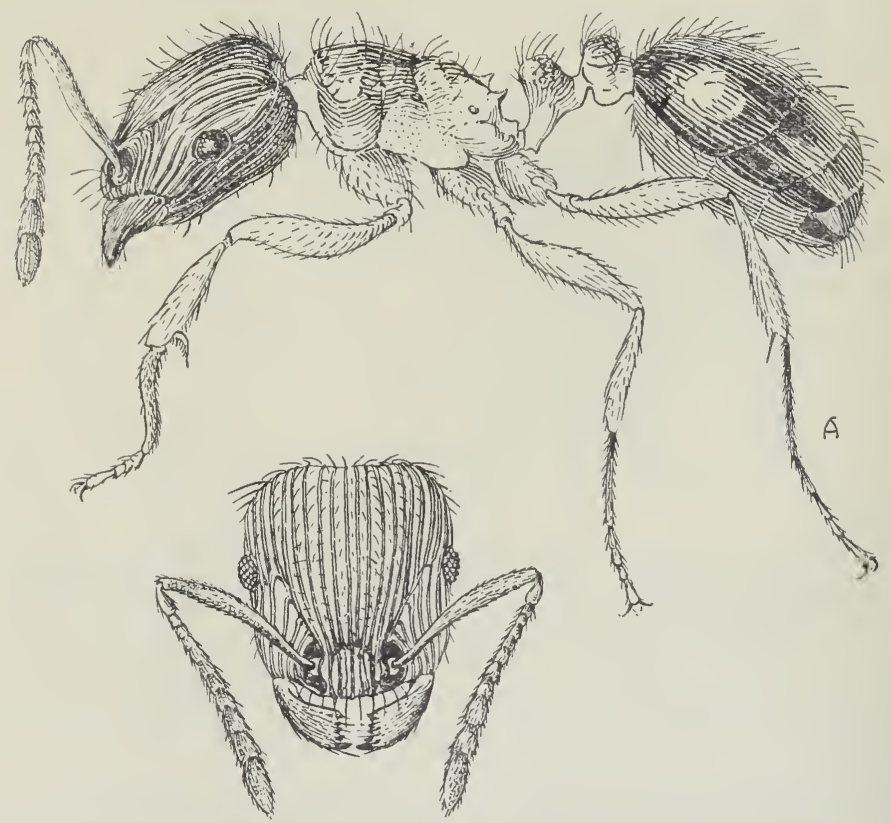

Fig. 21. - The pavement ant, Tetramorium caespitum Linn. Side worker ant and the front view of the head. $(\times 23$.

The jet-black harvester ant, Veromessor pergandei (Mayr.), 2.5 to 6 $\mathrm{mm}$ in length, occurs throughout the arid portions of the Southwest but in California is limited to the southern part of the state.

Having habits somewhat similar to those of the California agricultural ant, these ants may be controlled by similar methods.

\section{THE PAVEMENT ANT}

The pavement ant, Tetramorium caespitum (Linn.), is a small blackish-brown ant some 3 to $4 \mathrm{~mm}$ in length (fig. 21). The color of its body varies from light to very dark brown with the legs and antennae lighter in color than the body. The head and thorax are furrowed with parallel 
lines while the gaster is smooth. A pair of small spines occur on the posterior dorsal portion of the thorax and the body is sparsely covered with comparatively long, stiff hairs.

The pavement ant is an introduced species from Europe where it appears to be widely spread in typical meadow locations. In this country it became estabiished in the North Atlantic States and from there has been carried to other sections. In California it is found in many parts of the Sacramento Valley where it nests in lawns and under pavements and stepping stones from which vantage points it may range into the household in search of food. It destroys various plants by eating the bark

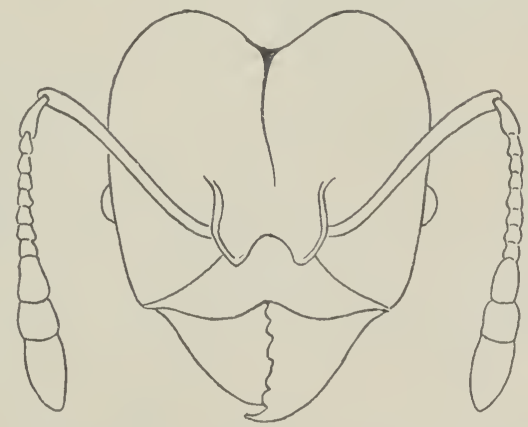

Fig. 22.-Head of Pheidole hyatti. This ant occasionally becomes a houseinvading pest in the vicinity of Fresno.

and cambium layers of the main stems and roots and where well established may become an agricultural pest of considerable importance. It also harbors and cares for aphids and, in doing so, causes additional injury to strawberries by removing the soil from the roots. It has been reported as a serious pest to strawberries in the Lodi district.

This slow-moving ant is best controlled by the insertion of soil fumigants into its nest, as described under "Fumigants," page 34. The spraying of plants with a nicotine and soap solution to destroy the aphids will aid in its control. The portions of plants above the ground can be protected by spraying or dusting with arsenicals or other stomach poisons. Other measures recommended for the control of the Argentine ant may be used where this ant becomes a pest in the household.

\section{THE BIG-HEADED ANT}

Ants of the genus Pheidole (fig. 22) live in situations somewhat similar to those inhabited by fire ants and are distributed throughout the warmer areas of the United States. Although superficially similar to the 
fire ants, they may be distinguished from the latter by their 12-jointed antennae and 3-jointed antennal club. At times they may cause annoyance in seedbeds and also in houses.

This ant may be controlled by methods recommended for the California fire ant. Hamlin ${ }^{6}$ found that Pheidole hyatti Emery could be effectively kept from refrigerators by standing the castors in small metal pars filled with a dry mixture of whiting and flowers of sulfur in ap-

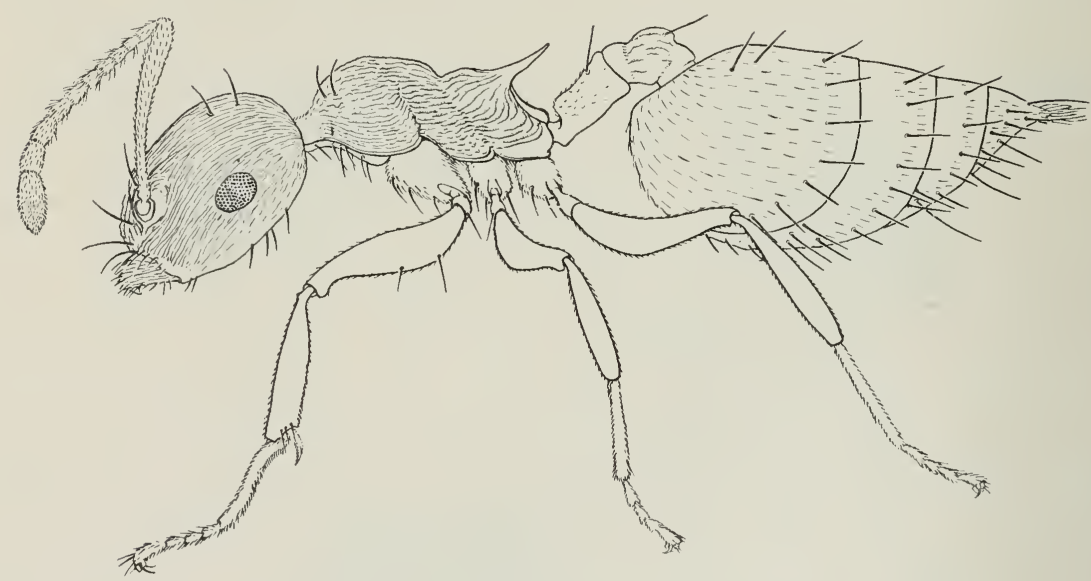

ox

Fig. 23.-Worker of the acrobat ant, Crematogaster sp. Notice the shape of the abdomen, which is often held up over the thorax. (From Bul. 207.)

proximately equal proportions. The pans were 4 inches in diameter and $1 \frac{1}{2}$ inches deep. The repellent quality of the powder will endure for a long period if the mixture is not moistened.

\section{THE LEAF-CUTTING ANT}

Only one species of the leaf-cutting, fungus-growing ant, namely Atta versicolor Pergande, is reported from California. It is a terrible scourge in the warmer parts of North and South America, but fortunately is rare in this state and is of no economic consequence here.

\section{THE ACROBAT ANT}

The acrobat ants, Crematogaster spp. (fig. 23), may be recognized by the heart-shaped abdomen, flattened on the upper surface and curved below. They are widely distributed throughout the country and in Cali-

${ }^{6}$ Hamlin, J. C. Inexpensive method of protecting household refrigerators from ants. Jour. Econ. Ent. $21: 2,431.1928$. 
fornia are often found under rocks. Their movements are slow and they have a peculiar habit of lifting' the abdomen over the head and thorax which has given rise to the name "acrobat." These ants tend aphids and are known to construct small "cowsheds" of vegetable fragments or earth as covers over aphids and coccids. They have little economic importance and may be controlled by the measures recommended for the Argentine ant.

\section{THE CALIFORNIA HONEY ANT}

The California honey ant, Prenolepis imparis var. californica Wheeler, is brownish black (fig. 24) and has a somewhat triangular abdomen. The worker is 2.3 to $2.5 \mathrm{~mm}$ in length, shiny brownish black, with antennae

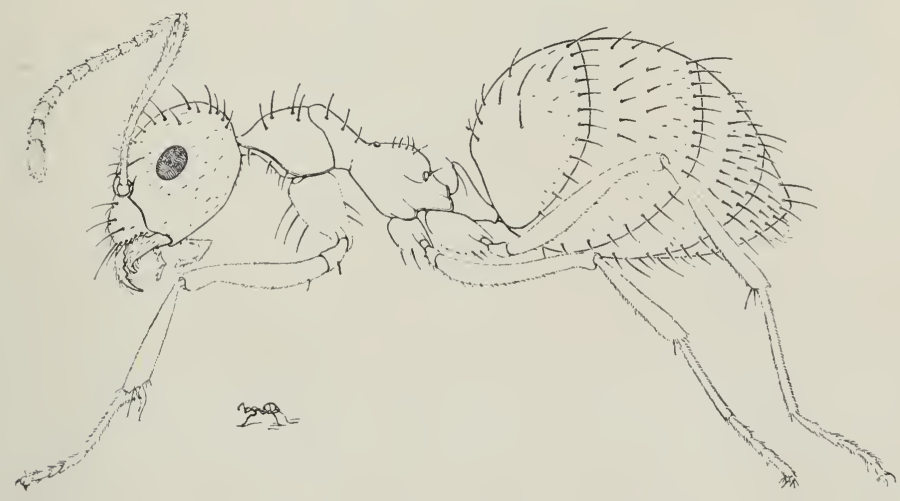

Fig. 24.-Worker of the California honey ant. Notice the shape of the abdomen. (From Bul. 207.)

and legs brown, tarsi paler and more yellowish. It is common throughout the state and may often be found ascending trees in the orchard. It feeds upon honeydew, as well as upon the exudates of young plant tissues; and in Los Angeles County is said to devour the tender growths of orange trees. After feeding, the abdomen of this ant becomes greatly distended and amber in color.

This species often replaces the Argentine ant whenever the latter has been eradicated. It may be controlled by the same methods as for that species.

\section{CARPENTER ANTS}

Carpenter ants, Camponotus spp. (fig. 25), are our largest ants in California and vary greatly in size. The workers are from 6 to $10 \mathrm{~mm}$ long; the queens from 13 to $15 \mathrm{~mm}$.

The maculate carpenter ant, Camponotus maculatus vicinus Mayr., and its varieties are large, attractive ants with a red thorax and a black 
abdomen. Maccook's maculate carpenter ant, Camponotus maculatus maccooki (Forel), though very similar to the above-mentioned species, differs in being paler, with the thorax and the first and second segments of the abdomen near the pedicel yellowish. These carpenter ants are rarely injurious in California although they at times forage in houses. Their presence there, however, is more or less accidental, the nests being usually situated in the soil some distance from the house; at times they may disfigure lawns with their mounds.

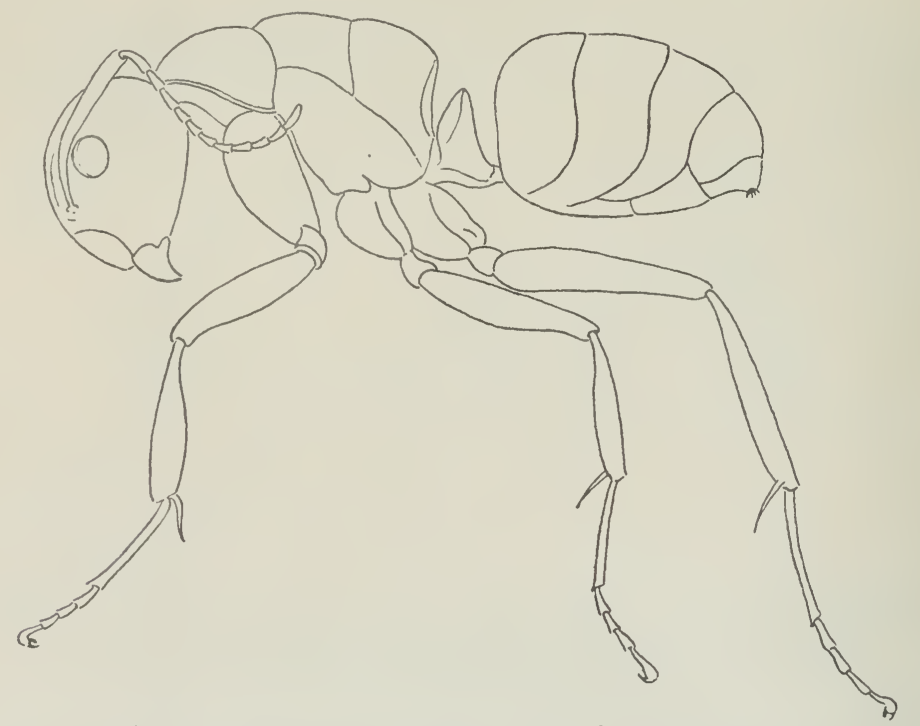

Fig. 25.-Worker of a carpenter ant, Camponotus sp.

Control.-Where control is required and whenever the nest of this ant can be located, destruction is possible through the use of kerosene and pyrethrum (formula 3), pyrethrum and soap emulsion (formula 7), carbon disulfide, or cyanide (see "Fumigants," pages 34-35).

Where the nest cannot be located, baits may be used. If these are placed in shaded places out of doors, the ants are more likely to be attracted to them. Tartar emetic sirup (formula 12) distributed in ant cans, has been used effectively. The entrances to the cans should be $1 / 4$ inch in diameter.

The giant carpenter ant, Camponotus levigatus, an all-black ant, and the Modoc carpenter ant, Camponotus herculeanus var. modoc, a black ant with reddish legs, are found in the mountains of California where they sometimes tunnel in the walls, rafters, and sills of log cabins. They may be controlled where necessary with tartar emetic (formula 12) dis- 
tributed in poison cans. The destruction of the ants in their burrows may be effected by injecting such fumigants as are listed under "Fumigants" on pages 34-35. Thoroughly soaking the timbers with kerosene will often drive the ants from their tumnels. Foundation timbers impregnated with creosote will repel the carpenter ants. The increased fire hazards of such timbers, however, should be taken into consideration. Control has also been effected by dusting powdered derris in the paths traversed by these ants in entering the walls of a home. As derris soon loses its toxicity on exposure to air, the dust should be reapplied every few days as long as the ants are present.

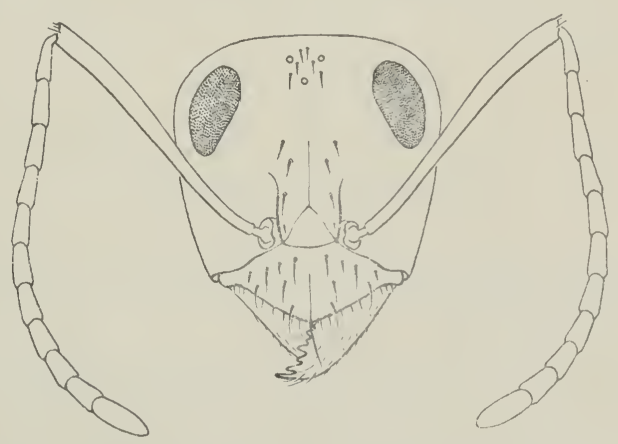

Fig. 26.-Face of the queen of a field ant, Formica sp. Notice the large eyes. (From Bul. 207.)

\section{FIELD ANTS}

Medium-sized ants of the genus Formica (fig. 26) occur in the fields at high and low altitudes everywhere in the state. Although they tend aphids, they are as a rule fiercely predaceous on insects.

The California brown field ants, Formica cinerea subspecies and varieties, are 3 to $7 \mathrm{~mm}$ in length, have a brownish-red thorax and a somewhat grayish abdomen. They are often found nesting in cracks in sidewalks, in nests with many entrances along the sides of buildings, and at the bases of trees. They may become obnoxious by foraging in houses and by tending aphids on trees and shrubs. These are the commonest Formica in California and are often observed running in long trails along fences, sidewalks, or buildings.

The California red and black field ant, Formica rufibarbis var. occidua Wheeler, is 4 to $7.5 \mathrm{~mm}$ in length, with the thorax red, the abdomen silvery black, and the top of the head dusky brown. This ant has approximately the same habits and distribution as the California brown field ants. It has a characteristic jerky method of running and stopping. 
The western mound-building ant, Formica rufa obscuripes Forel, varies from 3.8 to $8 \mathrm{~mm}$ in length, with the head and thorax red and the abdomen brownish black. It occurs at high altitudes (5,000 to 8,000 feet) in California and the northwestern states into British Columbia. Mounds are often constructed by this ant from small sticks, leaves, and pine needles. Ants building mounds in forested areas are often deleterious to seedlings and native growth adjacent. In Canada, R. C. Treherne ${ }^{7}$ states that these ants destroy pistils in the blossoms of fruit trees in order to reach the nectar, and thus cause considerable losses to fruit growers.

Control.-The field ants mentioned above may be controlled with soil fumigants (see "Fumigants," pages 34-35), as well as with ant sirup (formulas 8 and 9 ).

\section{LASIUS SPECIES}

Ants of the genus Lasius are often fairly important in the Middle West because they tend aphids in the fields. In California they cause little trouble.

They may be controlled when necessary by methods outlined for the control of the Argentine ant.

\section{MATERIALS AND FORMULAS USED IN ANT CONTROL}

Since many of the materials mentioned herein are poisonous to humans and to domestic animals, it is recommended that all formulas be mixed by druggists in order to reduce the dangers of accidental poisoning to the minimum.

\section{REPELLENTS}

The following materials have been used with varying degrees of success in repelling ants :

Camphor, naphthalene flakes, paradichlorobenzene, carbolic acid bands or emulsions, sulfur bands, corrosive sublimate, turpentine, coal oil, and oil of citronella.

Formula 1: Carbolic Acid Bands

Crude carbolic acid (phenol solution) ............ 1 pint

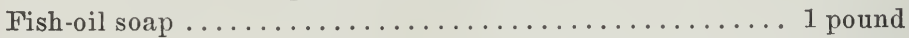

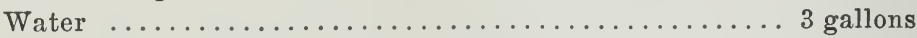

Ants often build their nests around the bases of trees, especially citrus trees. In such situations, strong solutions of cyanide or carbon disulfide will injure the tree. Crude carbolic acid is not very uniform. A pound of crystals can be substituted for the crude product in the formula given above.

${ }^{7}$ Treherne, R. C. Notes of economic interest from British Columbia. Can. Entom. 47:101-4. 1915 . 


\section{Formula 2: Sulfur Bands}

Finely pulverized sulfur ............. 1 part by weight

Commercial "tree-sticky" or tanglefoot.......6 parts by weight

The two ingredients should be mixed together thoroughly, without heat, by use of a wooden paddle. This mixture will remain effective in dry, foggy, or rainy weather, under all temperatures at which the ants will work, for periods of from 3 to 5 months. It appears to have a slightly repellent effect in addition to its more lasting viscosity. It must not be applied directly to the bark, for it will be absorbed to some extent and in time will injure the tree. The trunk should first be wound with hosemending tape, or with paraffined or moisture-proofed cloth, on which the banding material should then be applied. The band should be from 4 to 6 inches wide and nearly $1 / 4$ inch thick. If properly applied, these bands will need no attention for several months.

\section{CONTACT INSECTICIDES}

Saturation of the nest with kerosene is very effective against fire ants, lawn ants, and ants beneath or between paving stones. The kerosene kills on contact and makes the soil undesirable for nesting. Commercial fly sprays, pyrethrum mixtures, nicotine sulfate, soap emulsions, rotenone extracts, and combinations of pyrethrum and derris can also be used effectively to reduce the population of ants, but do not serve as permanent remedies.

Formula 3 : Kerosene and Pyrethrum Mixture

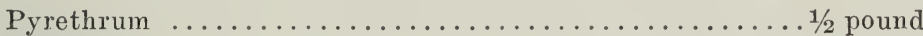

Kerosene ............................ 1 gallon

Mix thoroughly. After allowing to stand for about 12 hours, pour off the clear liquid. This mixture is useful against timber ants, which disappear when it is injected into the timbers occupied by them. It can also be used as a spray and kills all ants it covers. The better grades of kerosene should be used.

Formula 4: Nicotine Sulfate (Black Leaf 40)

Nicotine sulfate (commercial) ............... 1 part

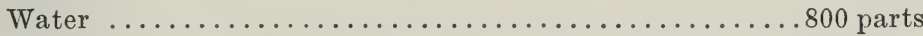

Nicotine sulfate kills the aphids on which ants feed and causes the ants to leave. Use this mixture as a spray.

FORMULA 5: SOAP WASH

Common laundry soap ................ to 1 pound

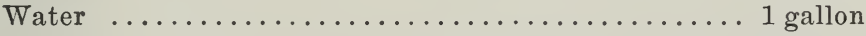

Use this wash, after soap has dissolved, on lawns that have become infested with ants. 
Rotenone extracts that readily emulsify with water can be used instead of nicotine sulfate to kill aphids. This material has been found to be very effective in dilutions of 1 to 400 in killing ants either on plants or as they travel in their trails.

Combinations of pyrethrum and derris in powder form will not only act as repellents but will kill ants that come in contact with them. The material can be dusted in ant trails and is especially effective in killing: and repelling ants if placed where they enter from the outside. The powders soon lose their toxicity on exposure to air and sunlight and must be renewed every few days.

\section{FUMIGANTS}

The most effective materials used as fumigants are carbon disulfide, cyanide, ethylene dichloride and carbon tetrachloride mixture, and pyrethrum and soap emulsion.

With a sharp-pointed stick, make several holes slightly larger than a lead pencil and about 6 to 8 inches deep, in the nest. The depth and number of the holes will vary with the nature of the nest. Into each pour about 1 tablespoonful of carbon disulfide, which may be applied with a machine oilcan. Cover the whole area treated with a metal tub, a wet canvas, a wet blanket, or a wet burlap bag. Carbon disulfide is a highly volatile inflammable liquid and mixtures of its vapor with air are highly explosive.

Calcium cyanicle is generally sold in the form of a powder for pest control.

A convenient method of placing the powder in the ant nest is to use a tin funnel with a long spout and a sharpened stick. After the hole is made with the stick inside the funnel, the stick is withdrawn, and the powcler poured into the hole through the funnel. The entire nest should then be covered with soil and the latter packed down firmly.

The amount of cyanide and the depth to which it is to be placed depend upon the size and construction of the nest. If Cyanogas is used, from $1 / 4$ to $1 / 2$ pound may be necessary for the larger nests of the harvester ants.

A cyanide solution can be made by dissolving one ounce of sodium cyanide in a gallon of water. The cyanide is generally sold in the form of balls of about one ounce, known as "Cyaneggs." The cyanide should be dissolved in enameled containers. Solution is hastened by crushing the cyanide.

The amount of solution needed will depend upon the size of the nest, an average-sized nest that extends for 8 to 12 inches in the soil will require at least a quart to eradicate all ant forms. It is generally desirable to 
scoop out a part of the soil over the nest and when the solution has been absorbed, fill in again with moist earth. The solution may also be poured down a number of holes made with a pointed rod to the depth of about 12 inches, after which the holes should be capped with moist earth. The fumes penetrate the tunnels of the ants and kill the adults and developing young. While trees and shrubs generally are not affected by this solution, tender, herbaceous shrubs may be injured. If one application is not sufficient, another should be made later.

Cyanide, a most powerful poison, must be handled carefully. It must be kept away from the mouth, from sores, and even from the wet skin. The fumes or dust should not be inhaled. Gas masks should be worn for
greatest safety.

Formula 6: Ethylene Dichloride and Carbon Tetrachloride Mixture

Sthylene dichloride $\ldots \ldots \ldots \ldots \ldots \ldots \ldots \ldots . \ldots \ldots$ parts (by volume)

Carbon tetrachloride ................ 1 part (by volume)

A fumigant liquid composed of the above mixture is much safer than carbon disulfide. This combination is not inflammable, explosive, or dangerous to handle. Ethylene dichloride used alone is inflammable and should be handled with due care.

Formula 7 : PyreThrum and SOAP EMULSION

Concentrated pyrethrum extract $\ldots \ldots \ldots \ldots \ldots \ldots \ldots \ldots$ p 1 part

(With ordinary household pyrethrum insecticides use 2 parts)

Soapy water ...........................1,000 parts

To kill colonies among growing plants, use formula 7 to wet the interior of the nests thoroughly. Scrape away the top of the nest to make a saucerlike depression and pour the liquid into this so that it will penetrate to the bottom of the nest.

\section{STOMACH POISONS}

Formula 8: Sodium Arsenite (U. S. Government Formula)

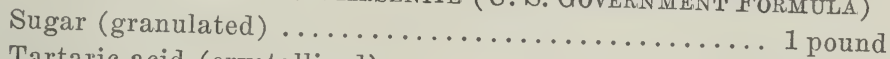

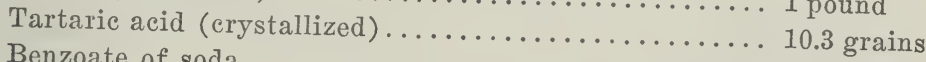

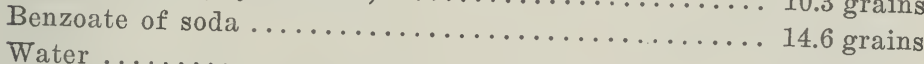

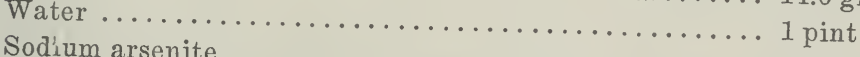

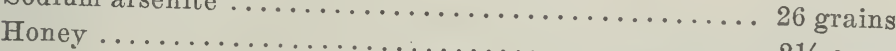

.

Specific directions for preparing this sirup are as follows:

Warm 1 pint of water in a clean vessel over a low fire. When it is tepid, add the tartaric acid, then benzoate of soda, and then the sugar, slowly; stir constantly to prevent burning. Measure the depth of the liquid with a stick. Slowly bring it to a boil, and allow it to simmer for 30 to 40 minutes. Remove from the stove, and add water to original depth 
on the measuring stick to make up for evaporation. Stir in the $21 / 3$ ounces of honey before the mixture cools. Then add 26 grains of sodium arsenite which has been dissolved in 1.8 fluid ounces of hot water and partially cooled before pouring into the sirup. Stir thoroughly. Apply in containers as previously described.

\section{Formula 9: The California Argentine Ant Sirup}

Honey (any aromatic kind) ................... 18 ounces

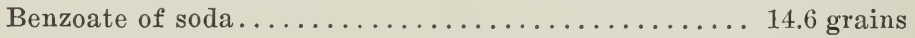

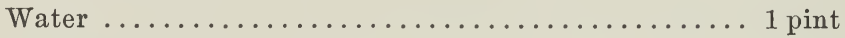

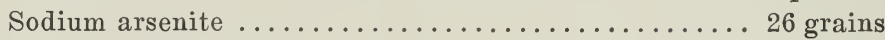

By substituting an equal amount of an aromatic honey for the sugar in formula 8, a poison sirup is obtained that will give as good or better results in the control of the Argentine and other sweet-loving ants. A dark off-grade honey will serve as well as a table variety of honey, and has the advantage of being cheaper.

Since honey contains primarily invert sugars, the tartaric acid can also be omitted. The mixture need be boiled for only a few minutes to insure a uniform solution and to destroy yeasts and mold-forming organisms. The sodium arsenite solution should be mixed thoroughly with the honey solution. The material should be stored for use in stoppered bottles properly labeled to indicate its poisonous nature. It is distributed in ant tins having openings too small for bees to enter.

Formula 10: Grease Baits

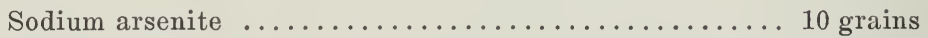

Grease ...................... 11/2 pints

Warm the grease and mix thoroughly with the sodium arsenite.

Pieces of bacon into which have been rubbed small quantities of sodium arsenite are also effective for fat- or grease-loving ants. The poisoned bacon should be cut in small pieces and distributed in ant tins as described for poisoned sirup mixtures.

Formula 11: Sodium Flluoride and Pyrethrum

Sodium fluoride .........................6 ounces

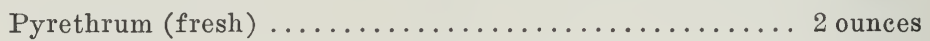

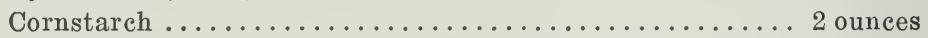

When dusted freely, this mixture has very effectively controlled Monomorium destructor on shipboard. It is also effective against the California velvety tree ant.

Formula 12: Tartar Emetic and Sugar Sir.up

Tartar emetic ................... 1 part by weight

Sugar ........................ 10 parts by weight

Water.$\ldots \ldots \ldots \ldots \ldots \ldots \ldots \ldots \ldots \ldots \ldots \ldots$ parts by weight

This should be thoroughly mixed. It is not effective against the Argen- 
tine ant. The addition of honey makes it more attractive to ants. This material may be put out in ant tins located in areas where the ants abound or spread on small pieces of wood or paper and placed in situations available to the ants. The bait should be renewed from time to time until the ants disappear.

Formula 13: PARIS Green ANd Sugar

Paris green .............................. 1 ounce

Brown sugar $\ldots \ldots \ldots \ldots \ldots \ldots \ldots \ldots \ldots \ldots \ldots \ldots \ldots \ldots \ldots$ pound

Mix together thoroughly and place small quantities under boards or stones where ants occur, or in the vicinity of ant nests. Replenish after each rain or irrigation for the material is effective only so long as the sugar remains comparatively dry. Paris green is an arsenical poison and should be handled with due care because of its danger to children and domestic animals. Mix only sufficient of the poison for each application as the material might be mistaken for green sugar.

\section{ANTIDOTES AND EMETICS ${ }^{8}$}

Avoid the need of antidotes and emetics by exercising care in properly labeling poison containers, and by storing them out of reach of children and away from foodstuffs or medicines, and by using extreme care in handling the poisons.

\section{GENERAL INSTRUCTIONS}

In Case of Poisoning Call a Physician Immediately. Until the physician arrives follow the directions here given.

When the nature of the poison is unknown, the following is a good antidote to most poisons, but of little or no value in poisoning by antimony, caustic alkalies, or phosphorus:

Equal parts of magnesia, charcoal (wood), and hydrated oxide of iron, mixed and freely given in water ( 2 ounces of each to 12 ounces of water). The magnesia is given to neutralize any acid that may be present; the charcoal, to precipitate or absorb any alkaloid; and the hydrated oxide of iron, to combine with any arsenical compound. On a similar basis, the following may be given :

Magnesia, 1 tablespoonful; tannic acid, 1 tablespoonful ; charcoal, 2 tablespoonfuls. Mix and give 1 teaspoonful, stirred in water, every 5 to 15 minutes. Evacuate the stomach soon after using this antidote.

${ }^{8}$ The antidotes and emetics given herein have for the most part been taken from: California State Board of Pharmacy. Official antidotes. 7 p. July 1, 1935. Bound in: Pharmacy law, poison law, veronal law, vendor law, and inspection record. California State Board of Pharmacy. July 1, 1935.

Some have also been taken from: Brundage, Albert. Manual of toxicology. 15th ed.. 444 p. D. Appleton and Co., New York, N. Y., 1929. 
The emetics, demulcent drinks, stimulants, and sedatives mentioned in connection with the specific antidotes are best made as follows:

Emetics.-Mix from 2 to 4 teaspoonfuls of mustard in a cupful of warm water and stir to a thick cream, or give from 15 to 30 grains of powdered ipecac in water ; repeat every 10 to 15 minutes. Or give from 5 to 10 grains of sulfate of zinc in water and repeat until free vomiting is produced. (Do not give zinc sulfate if salt and water have been given previously.)

Demulcent Drinks.-Flaxseed or slippery elm tea, barley water, thin starch, water, milk, white of eggs mixed with water, or thin flour paste; give any of these very freely.

Stimulants.-Put from 10 to 20 drops of aqua ammonia in half a glass of water ; or put from $1 / 2$ to 1 teaspoonful of aromatic spirits of ammonia in $1 / 2$ glass of water; give for one dose and repeat as needed.

Sedatives.-Give from 1 to 2 tablespoonfuls of paregoric in one-half glass of water; or give 30 grains of potassium bromide in water for a dose and repeat as required.

\section{SPECIFIC ANTIDOTES}

Arsenic and Its Compounds.-Emetic of mustard (see above); hydrated oxide of iron and magnesia, a cupful; follow with olive oil or white of eggs, mucilaginous drinks; 30 grains potassium bromide in water ; if much pain, give 2 tablespoonfuls paregoric in water.

Carbolic Acid (Phenol).-Dilute alcohol, 4 tablespoonfuls of alcohol with equal amount of water, followed immediately by an emetic of mustard; repeat three or four times and give albuminous substances, milk or white of eggs. Follow with Epsom salts.

Carbon Disulfide and Carbon Tetrachloride.-If vomiting has not occurred, resort promptly to any method of flushing out the stomach, or to the use of emetics.

Corrosive Sublimate (Bichloride of Mercury).-Fantaus antidote, white of eggs, flour or starch mixed with water. Follow with an emetic of mustard. Afterward give strong tea or coffee; stimulants of diluted alcohol, or a teaspoonful of aromatic spirits of ammonia in water, and lastly, demulcent drinks. (Fantaus solution is made as follows : sodium hypophosphite, 5 grams; hydrogen peroxide, 25 cc; distilled water, 50 cc. This amount is necessary to neutralize one antiseptic tablet of 0.5.)

Cyanide (Hydrocyanic Acid).-For cyanide gas poisoning inhale strong ammonia fumes intermittently. Keep patient quiet and warm. If not breathing normally, administer artificial respiration. Give $1 / 2$ teaspoonful aromatic spirits of ammonia in 2 ounces of water by mouth. 
For cyanide poison swallowed cause vomiting without delay by putting a finger down the throat. Cause patient to swallow a mixture of 2 fluid ounces each of ferrous sulfate (15 per cent solution) and sodium carbonate (6 per cent solution). Inhale ammonia fumes and apply artificial respiration. Keep patient quiet and warm.

Sodium Fluoride.-Give at once large draughts of lime water or weak calcium chloride solution, stimulants of strong coffee or aromatic spirits of ammonia; artificial respiration; keep lower extremities and chest warm; give digitalis hypodermically (administered by doctor).

Nicotine Sulfate (Black Leaf 40)._Drink warm water freely; give emetic of mustard or empty the stomach with a stomach tube. Give strong tea or coffee, aromatic spirits of ammonia, 1 teaspoonful in water. Keep lower extremities and chest warm. Give $1 / 30$ grain strychnine hypodermically every hour until four doses are taken (administered by doctor).

Pyrethrum.-Cause vomiting and evacuation.

Tartar Emetic (Antimony).-Tannin or tannates (strong tea or infusion of oak bark) emetic of mustard and large draughts of warm water; afterward white of eggs or milk. 
